\title{
Recent Advances of Near-Infrared (NIR) Emissive Metal Complexes Bridged by Ligands with $\mathrm{N}$ - and/or O-Donor Sites
}

\author{
Jian-Xun Liu ${ }^{1}$, Shi-Lin Mei ${ }^{1}$, Xian-He Chen ${ }^{1}$ and Chang-Jiang Yao ${ }^{1,2, *}$ \\ 1 State Key Laboratory of Explosion Science and Technology, School of Mechatronical Engineering, \\ Beijing Institute of Technology, Beijing 100081, China; 3120205150@bit.edu.cn (J.-X.L.); \\ 6120200157@bit.edu.cn (S.-L.M.); 3120200177@bit.edu.cn (X.-H.C.) \\ 2 Beijing Institute of Technology Chongqing Innovation Center, Chongqing 401120, China \\ * Correspondence: cjyao@bit.edu.cn
}

Citation: Liu, J.-X.; Mei, S.-L.; Chen, X.-H.; Yao, C.-J. Recent Advances of Near-Infrared (NIR) Emissive Metal Complexes Bridged by Ligands with $\mathrm{N}$ - and/or O-Donor Sites. Crystals 2021, 11, 155. https://doi.org/10.3390/ cryst11020155

\section{Academic Editor:}

Alessandro Chiasera

Received: 30 December 2020

Accepted: 31 January 2021

Published: 3 February 2021

Publisher's Note: MDPI stays neutral with regard to jurisdictional claims in published maps and institutional affiliations.

Copyright: (c) 2021 by the authors. Licensee MDPI, Basel, Switzerland. This article is an open access article distributed under the terms and conditions of the Creative Commons Attribution (CC BY) license (https:/ / creativecommons.org/licenses/by/ $4.0 /)$.

\begin{abstract}
Near-infrared (NIR) emissive metal complexes have shown potential applications in optical communication, chemosensors, bioimaging, and laser and organic light-emitting diodes (OLEDs) due to their structural tunability and luminescence stability. Among them, complexes with bridging ligands that exhibit unique emission behavior have attracted extensive interests in recent years. The target performance can be easily achieved by NIR light-emitting metal complexes with bridging ligands through molecular structure design. In this review, the luminescence mechanism and design strategies of NIR luminescent metal complexes with bridging ligands are described firstly, and then summarize the recent advance of NIR luminescent metal complexes with bridging ligands in the fields of electroluminescence and biosensing/bioimaging. Finally, the development trend of NIR luminescent metal complexes with bridging ligands are proposed, which shows an attractive prospect in the field of photophysical and photochemical materials.
\end{abstract}

Keywords: near-infrared; metal complexes; bridging ligands; luminescence; imaging

\section{Introduction}

Coordination compounds, such as Prussian blue and bile alum as dyes and fungicides, respectively, have been used in living very early on. However, it was not until 1798 that metal complexes were systematically studied for the first time. Tassael used divalent cobalt salt, $\mathrm{NH}_{4} \mathrm{Cl}$, and $\mathrm{NH}_{3} \cdot \mathrm{H}_{2} \mathrm{O}$ to prepare $\mathrm{CoCl}_{3} \cdot 6 \mathrm{NH}_{3}$, and subsequently discovered that other metals, such as chromium, nickel, copper, and platinum, and combining $\mathrm{Cl}-, \mathrm{CN}-$, $\mathrm{H}_{2} \mathrm{O}$, and $\mathrm{CO}$ can generate similar compounds. It is worth mentioning that Zeise synthesized the first organic-metal complex $\mathrm{K}\left[\mathrm{PtCl}_{3}\left(\mathrm{C}_{2} \mathrm{H}_{4}\right)\right] \cdot \mathrm{H}_{2} \mathrm{O}$ by adding $\mathrm{PtCl}_{4}$ into boiling ethanol in $1827[1,2]$. The successfully generated $\mathrm{K}\left[\mathrm{PtCl}_{3}\left(\mathrm{C}_{2} \mathrm{H}_{4}\right)\right] \cdot \mathrm{H}_{2} \mathrm{O}$ by the combination of organic ligands and metal atoms or ions has greatly expanded the research field of coordination chemistry. Taking advantage of the structural diversity of organic molecules, metal complexes with organic molecules as ligands have been extensively reported and displayed wide application in chemical sensing, ion detection, biological probes, etc. [3-6] Traditional organic-metal complexes are mainly divided into mononuclear complexes and multinuclear complexes. Mononuclear complexes have only one central metal atom, while multinuclear complexes contain two or more central metal atoms. Multi-nuclear coordination compounds usually link the central metal atom through bridge ligands. Compared to mononuclear metal complexes, the central metal electron transfer by metal-metal bonds or bridge ligands can cause them to exhibit many excellent properties in physical/chemical functions and biological activities [7]. Consequently, bridged coordination compounds have become one of the most active research hotspots in coordination chemistry and have shown extensive applications in the fields of light, electricity, magnetism, catalysis, etc. [8-13]. In this review, we mainly focus on the research of near-infrared (NIR) emissive metal complexes with bridging ligands in the last decade. 
NIR emission in the range of $700-1700 \mathrm{~nm}$, showing unique photophysical and photochemical performance, has exhibited great promise for a variety of applications in many fields, such as optical telecommunication, biological imaging, sensing, lasers, solar energy conversion, etc. [14-20]. To date, the NIR emissive materials can be divided into four categories, i.e., organic molecules, conjugated polymers, surface-modified inorganic nanoparticles, and metal-organic complexes. However, although the structures of organic molecules are adjustable, they usually suffer from problems including irresistance to photobleaching and small Stokes shift [18]. Inorganic nanomaterials have excellent stability, but their structure is relatively simple. Hence, metal-organic complexes, benefiting from the tunable structure of organic ligands and good stability of inorganic metal ions, have been considered as ideal materials in the field of NIR luminescence research.

\section{Emission Mechanism of Metal Complexes}

The emission nature of metal-organic complexes depends strongly on the relative energy level of the lowest excited state of metal atom(s) and organic-ligand(s). As shown in Figure 1, according to the relative position of the energy levels between metal ion excited state $\left(\mathrm{M}^{*}\right)$ and the lowest excited singlet state $\left(\mathrm{S}_{1}\right)$ and lowest excited triplet state $\left(\mathrm{T}_{1}\right)$ of the organic ligand, there are four excited state charge transfer modes.

I

II $\quad$ III

IV

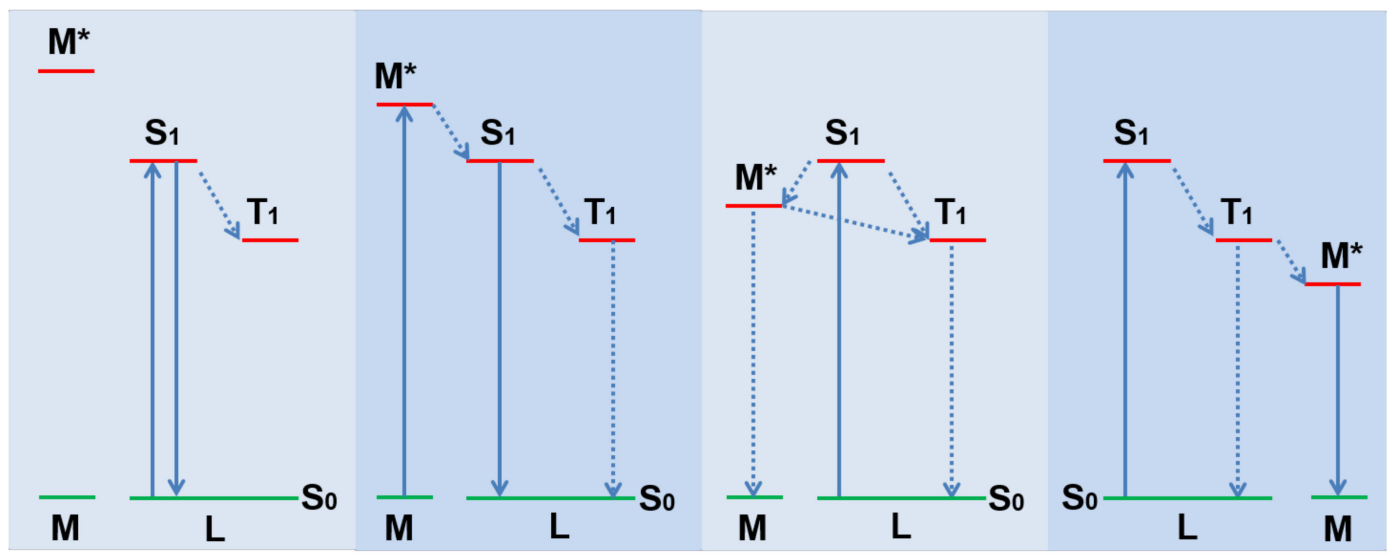

Figure 1. The excited state charge transfer mode between metal ion and organic ligand of metal complexes.

The first mode (Figure 1, mode I), i.e., intra-ligand charge transfer (ILCT), is usually observed in luminescent metal complexes based on emissive organic-ligands [21,22]. The large energy gap between $M^{*}$ and the ligand $S_{1}$ results in their excited state energy levels not overlapping with each other, and the intersystem crossing (ISC) cannot conduct. Therefore, the light emission of the complex is mainly attributed to the organic ligand. Here, the main role of metal ions is to increase the rigidity of the complex, leading to the transition of the lowest excited state of the organic ligand from $n \rightarrow \pi^{*}$ to $\pi \rightarrow \pi^{*}$ accompanied by significant changes in the emission performance [23,24].

The second mode (Figure 1, mode II), i.e., metal-to-ligand charge transfer (MLCT) transition, commonly occurs in luminescent complexes where metals are easily oxidized and ligands are facilely reduced [25]. Although the energy level of $\mathrm{M}^{*}$ is still higher than that of the organic ligand $S_{1}$ state, an appropriate energy gap is maintained between them. The $\mathrm{M}^{*}$ state can transfer energy to $\mathrm{S}_{1}$ state of the organic ligands through coordination bonds. If the sensitized ligands dissipate the energy by their lowest excited singlet or triplet state radiation transitions, their complexes would show luminescence [26]. Transition metal (e.g., $\mathrm{Rh}, \mathrm{Ru}, \mathrm{Os}, \mathrm{Ir}$, and $\mathrm{Re}$ ) as the coordination central ions is common in luminescent complexes forming this excited state charge transfer [27]. 
For the third mode (Figure 1, mode III), the energy gap between the organic-ligand $\mathrm{S}_{1}$ and $M^{*}$ is smaller than that between $S_{1}$ and $T_{1}$, so the charge of $S_{1}$ first transitions to $M^{*}$ instead of directly returning to $S_{0}$ or $T_{1}$. In addition, since the energy gap between organicligand $T_{1}$ and $\mathrm{M}^{*}$ is smaller than that between $\mathrm{M}^{*}$ and $\mathrm{M}$, the charge at $\mathrm{M}^{*}$ tends to return to organic-ligand $\mathrm{T}_{1}$ first instead of directly returning to $\mathrm{M}$. Therefore, due to the long pathway of the intersystem crossing, most of the excited state energy is dissipated via non-radiative transitions, resulting in particularly weak or no luminescence of the complex. It is quite clear that this excited state charge transfer mode should be avoided in the study of luminescent metal complexes.

Ligand-to-metal charge transfer (LMCT) is another common approach of excited state charge transition in luminescent metal complexes (Figure 1, mode IV), which is generally found in complexes with luminescent transition metal, especially the lanthanides, as the coordination center. This is because the forbidden $\mathrm{d}-\mathrm{d}$ or $\mathrm{f}-\mathrm{f}$ transitions make low absorption cross-sections of transition metal elements, and they are difficult to directly excite. Therefore, high absorption organic ligands are used to coordinate with these emissive metal ions, which realizes energy transfer from the excited state of light-harvesting organic ligands to the metal center and enhances the luminescence of metal elements under low power excitation. The light-harvesting chromophore which is used to sensitize the central metal is called antenna ligand. An ideal antenna ligand should have excellent coordination ability with transition metals, high extinction coefficient, and appropriate energy gap with $\mathrm{M}^{*}[28,29]$.

Metal complexes not only have abundant forms of excited luminescence, but also countless possible combinations of metal atom(s) and ligand(s), which could lead to different yet tunable spectroscopic and excited-state properties [30]. Besides, electronexcited metal complexes can carry out electron transfer and/or energy transfer with other molecules, and in the microenvironment, subtle changes would significantly perturb their luminescence, especially the charge-transfer excited metal complexes, which are the reason for their many applications.

\section{Bridging Ligands}

Organic-ligands containing oxygen and nitrogen have been extensively used to combine with metal ions to build metal-organic complexes since the fact that $\mathrm{O}$ or $\mathrm{N}$ atom contains lone electron pairs, while metal atoms' empty orbitals can accept electrons [28]. As for bridging ligand, it commonly contains more than one $\mathrm{O}$ or $\mathrm{N}$ which participates in the coordination with metal ions. Herein, according to the types of organic ligands coordination groups, we summarize the NIR emissive complexes based on the types of coordinated organic ligands and divide the commonly used bridging ligands into several types as follows.

\subsection{Polypyridine Bridging Ligand}

The most used N-heterocycle bridging ligands in coordination chemistry of NIR emission are undoubtedly 4,4'-bipyridine (4,4'-bpy) (1) and trans-bis(4-pyridyl)ethylene $\left(4,4^{\prime}\right.$-bpe) (2) (Figure 2). Although their molecular structures are simple, they are often used as auxiliary ligands to bridge two metal ions for changing the luminescence properties of metal complexes. The tail $\mathrm{N}$ atoms of N-heterocycle bridging ligands can coordinate with the metal ions to realize metal complexes from mononuclear to multinuclear or from low-dimensional to high-dimensional transition [31]. For example, Lü et al. synthesized two tetranuclear metal complexes, $\left[\mathrm{Zn}_{2} \mathrm{Nd}_{2} \mathrm{~L}_{2}-\left(4,4^{\prime}-\right.\right.$ bpy $\left.)\left(\mathrm{NO}_{3}\right)_{6}\right] \cdot \mathrm{Et}_{2} \mathrm{O}$ and $\left[\mathrm{Zn}_{2} \mathrm{Nd}_{2} \mathrm{~L}_{2}\left(4,4^{\prime}-\right.\right.$ bpe)] $2 \mathrm{H}_{2} \mathrm{O}$, using $4,4^{\prime}$-bpy and $4,4^{\prime}$-bpe to bridge the simple dinuclear $\mathrm{Zn}-\mathrm{Nd}$ complex [ $\left.\mathrm{ZnNdL}\left(\mathrm{H}_{2} \mathrm{O}\right)\left(\mathrm{NO}_{3}\right)_{3}\right]$, respectively [32]. The constructed multinuclear heterometallic $3 \mathrm{~d}-4 \mathrm{f}$ Schiff-base metal complexes $\left[\mathrm{Zn}_{2} \mathrm{Nd}_{2} \mathrm{~L}_{2}-\left(4,4^{\prime}-\right.\right.$ bpy $\left.)\left(\mathrm{NO}_{3}\right)_{6}\right] \cdot \mathrm{Et}_{2} \mathrm{O}$ and $\left[\mathrm{Zn}_{2} \mathrm{Nd}_{2} \mathrm{~L}_{2}\left(4,4^{\prime}-\right.\right.$ bpe) $] \cdot 2 \mathrm{H}_{2} \mathrm{O}$ with different bidentate linkers exhibited distinct luminescent properties due to the inherent characters of the bridging ligands. 


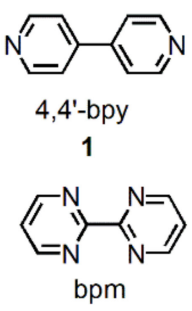

3

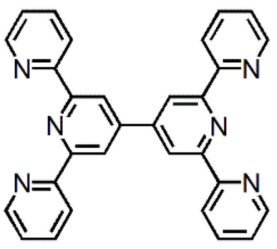

7

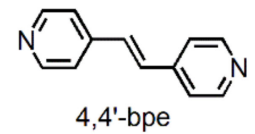

2
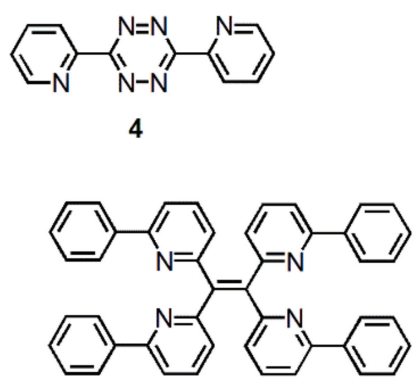

8<smiles></smiles>

5

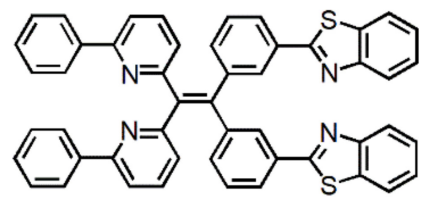

9

Figure 2. Some polypyridine bridging ligands mentioned in this chapter.

Although 2,2'-bipyridine is an isomer of 4, $4^{\prime}$-bipyridine, its two nitrogen atoms coordinate with only one metal ion, which results in the inability to form a bridge and thus limits its function as a bridging ligand in the construction of metal complexes. Nevertheless, organic bridging ligands with multiple 2,2'-bipyridine units offset the disadvantage and have attracted widespread attention in NIR luminescent metal complexes [33]. In addition, 2,2'-bipyrimidine (bpm) (3) has to be mentioned because of its similar structure to 2,2'-bipyridine, but can be used as a bridging ligand to connect two metal ions. For example, in 2005, Shavaleev et al. used 2,2'-bipyrimidine as a bridging ligand to connect mononuclear complexes $\left[\operatorname{Re}(\mathrm{bpm})(\mathrm{CO})_{3} \mathrm{Cl}\right]$ and $\left[\mathrm{Pt}(\mathrm{bpm})\left(\mathrm{CC}-\mathrm{C}_{6} \mathrm{H}_{4} \mathrm{CF}_{3}\right)_{2}\right]$ to lanthanide metal ions, and prepared NIR luminescent heterobinuclear metal complexes $\left[\operatorname{Re}(\mathrm{CO})_{3} \mathrm{Cl}(\mu-\mathrm{bpm}) \mathrm{Ln}(\text { fod })_{3}\right]$ (abbreviated as $\mathrm{Re}-\mathrm{Ln}$; where $\mathrm{Ln}=\mathrm{Yb}, \mathrm{Nd}$, Er; fod = ${ }^{t} \mathrm{BuC}(\mathrm{O}) \mathrm{CH}_{2} \mathrm{C}(\mathrm{O}) \mathrm{CF}_{2} \mathrm{CF}_{2} \mathrm{CF}_{3}$.) and $\left[\left(\mathrm{F}_{3} \mathrm{C}-\mathrm{C}_{6} \mathrm{H}_{4}-\mathrm{CC}\right)_{2} \mathrm{Pt}\left(\mu\right.\right.$-bpm) $\left.\mathrm{Ln}(\mathrm{hfac})_{3}\right]$ (abbreviated as $\mathrm{Pt}-\mathrm{Ln}$; where $\mathrm{Ln}=\mathrm{Nd}$, $\mathrm{Gd}$; hfac $\left.=\mathrm{CF}_{3} \mathrm{C}(\mathrm{O}) \mathrm{CH}_{2} \mathrm{C}(\mathrm{O}) \mathrm{CF}_{3}\right)$ [34]. Li et al. synthesized a series of homodinuclear lanthanide complexes $\mathrm{Ln}_{2}(\mathrm{HTH})_{6} \mathrm{bpm}$ (where $\mathrm{Ln}=\mathrm{Eu}, \mathrm{Sm}, \mathrm{Er}, \mathrm{Yb}, \mathrm{Pr}$; $\mathrm{HTH}=4,4,5,5,6,6,6$-heptafluroro-1-(2-thienyl)hexane-1,3-dione) using 2,2'-bipyrimidine as a bridge ligand and described these complexes photoluminescence properties in 2009 [35].

With the development of research on emissive metal complexes, small molecule bridging ligands have been unable to meet the study requirements. Therefore, a large number of functionalized large polypyridine organic ligands have been designed and synthesized for the preparation of NIR emissive metal complexes [33,36-38]. As shown in Figure 2, from 4 to 9, not only the relative molecular weight of bridging ligand distinctly increases, but also their structure with special functions gradually becomes complicated. Whereas, it should be noted that the design principle of these molecules is consistent, i.e., combining bipyridine-like units and metal ions to form NIR emissive metal complexes.

In 2019, Moustafa et al. have prepared bimetallic Pt(II) complexes 10 and 11 (Figure 3) through bridging ligands $\mathbf{8}$ and $\mathbf{9}$, the hypothesis that the introduction of additional $\mathrm{Pt}$ centers into the tetraarylethylene scaffold will further enhance the likelihood of metal-metal interactions upon aggregation-induced self-assembly has been tested, and in turn resulting in even further bathochromic shifts in emission into the NIR region [38]. By the addition of Tris buffer ( $\mathrm{pH} 7.5$ ) into 11, the absorption peak changed from $397 \mathrm{~nm}$ to $621 \mathrm{~nm}$, and the gradual emergence of the NIR emission peak $\left(\lambda_{\max }=785 \mathrm{~nm}\right)$ was detected in the luminescence spectrum. These spectral changes are attributed to aggregation of $\mathbf{1 1}$ via metal-metal and/or $\pi-\pi$ stacking interactions, as has been previously reported for other platinum(II) complexes. 
10

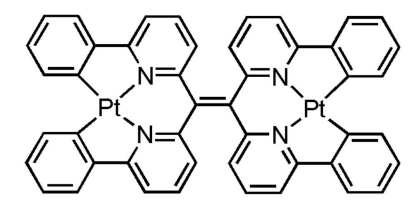

11

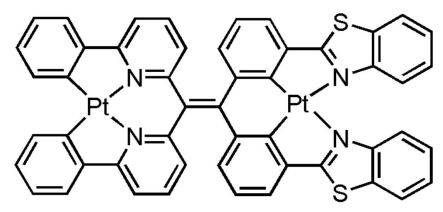

Figure 3. Structures of $\mathrm{Pt}(\mathrm{II})$ complexes 10 and 11. Adapted from ref. [38].

\subsection{Polypyrrole Bridging Ligand}

Porphyrin, the macrocyclic compounds formed by the interconnection of $\alpha$-carbon atoms of four pyrrole methylene groups via a methine bridge $(=\mathrm{CH}-)$, has been widely used as representative of polypyrrole ligands in coordination chemistry [39]. This is because porphyrin has the following advantages: (i) Porphyrins have strong chromophore absorption in both ultraviolet and visible light regions; (ii) its tetraaza macrocyclic core can coordinate with most metal ions; (iii) the backbone may be readily modified by introducing functional group at meso and/or $\beta$-pyrrolic positions, resulting in appearing a large variety of possibilities and variations; (iv) its excited state levels are excellently adapted for the sensitization of Ln(III) NIR emitters [39].

Thereupon, the strategy of modifying the group with coordination sites on the periphery of the porphyrin core as a bridging ligand for the synthesis of NIR light-emitting complexes has been proposed. The advantage of this system is that the energy level of the excited state of the chromophore can be fine-tuned by the combination of metal cations with the tetraaza nucleus of the porphyrin. Furthermore, by increasing or decreasing the distance between the porphyrin core and peripheral coordination atoms, i.e., controlling antenna ligand length, NIR luminescence properties can be tuned. In 2000, Beeby et al. first realized this strategy [40]. They synthesized a palladium porphyrin with a chiral cyclization group, which was covalently linked to the porphyrin backbone via the $\beta$-pyrrole position (Figure 4). The excitation of porphyrin at $529 \mathrm{~nm}$ caused the emission at $980 \mathrm{~nm}$ for the $\mathrm{Yb}$ complex and $870 \mathrm{~nm}$ and $1064 \mathrm{~nm}$ for the $\mathrm{Nd}$ complex. The phosphorescence of Pd porphyrin was observed in both cases. Since then, this type of ligand has been designed and synthesized purposefully by the researcher and applied to the study of NIR light-emitting metal complexes.

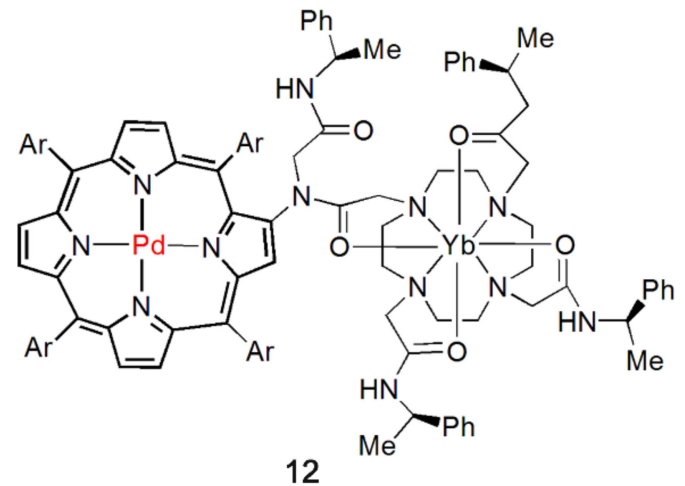

Figure 4. Structure of complex 12. "Ar" is an abbreviation for "Aryl". Adapted from ref. [40].

Rusakova et al. reported the polydentate ligands by coupling mono-4-aminotetraphenylporphyrin with the anhydride of the ethylenediaminetetraacetic acid (EDTA) or the diethylenetriaminepentaacetic acid (DTPA) and constructed NIR radiative metal complexes 
in 2010 [41]. These ligands have been obtained by covalently binding porphyrin core with penta- or hepta-dentate ligands. As shown in Figure 5, the corresponding photophysical properties of $\mathrm{Yb}$ complexes and other metal complexes $(\mathrm{Zn}$ and $\mathrm{Cu}$ ) were studied. The results showed that energy was transferred from porphyrin antenna to $\mathrm{Yb}$ ion. Due to the good shielding effect of the emitter, the near-infrared radiation of heptadentate ligand was slightly enhanced. However, the existence of $\mathrm{Cu}$ or $\mathrm{Zn}$ ions in the porphyrin cavity led to the quenching of the NIR emission.

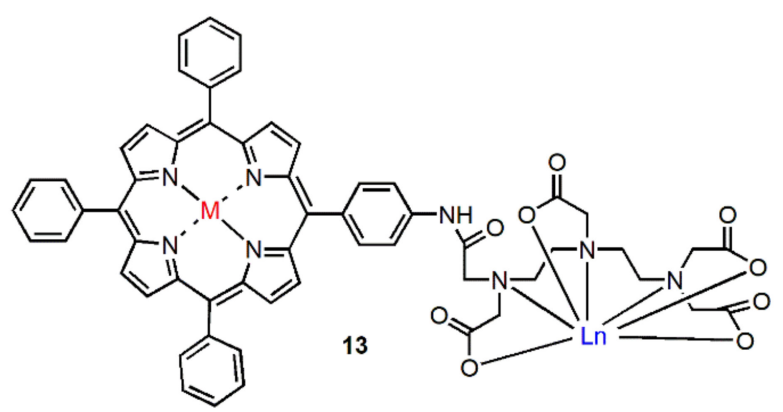

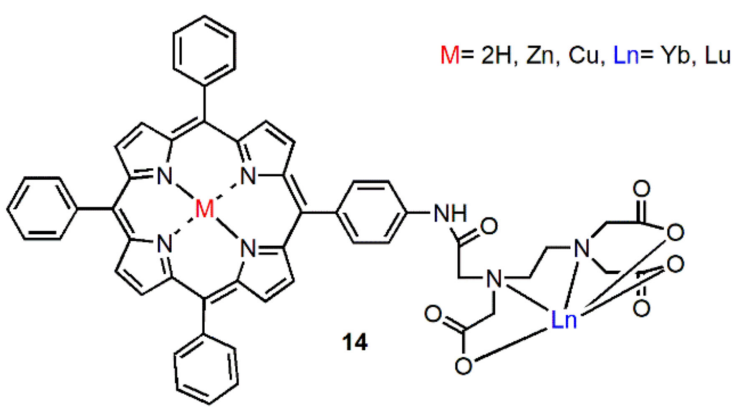

Figure 5. Structures of complexes 13 and 14. Adapted from ref. [41].

In 2018, Xiong et al. synthesized a series of metal complexes by using porphyrin derivative as organic bridging ligands [42]. As shown in Figure 6, the free base and Pd chelate chlorins were appended to the 4-position of the dipicolinic acid through either the 3or the 15-position of the chlorin to form bridging ligands. The excitation of porphyrin derivatives at $590 \mathrm{~nm}$ induced the emission at $980 \mathrm{~nm}$ for the $\mathrm{Yb}$ complex and $890 \mathrm{~nm}$ and $1064 \mathrm{~nm}$ for the Nd complex. In this report, the combination of narrow Ln emissions with narrow chlorin absorptions provides avenues for excitation and emission-based multiplex imaging.

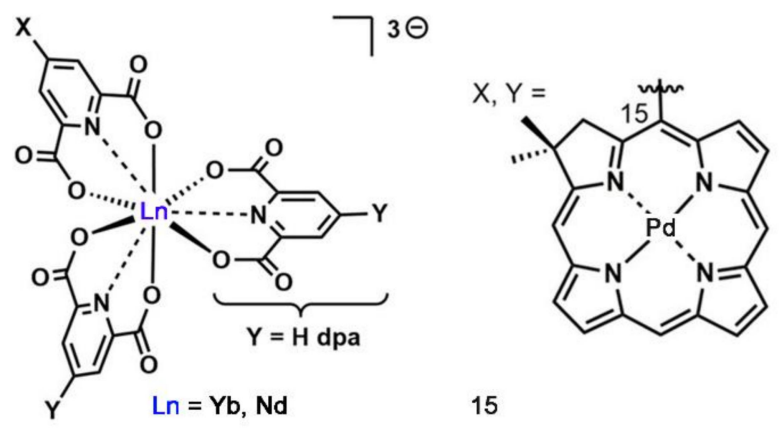

Figure 6. Structures of $\mathrm{Yb}$ and $\mathrm{Nd}$ complexes. Reprinted with permission from [42]. Copyright 2018, American Chemical Society.

In addition, some polypyrrole bridging ligands which are similar to those in Figure 7 have been designed, synthesized, and used to construct near-infrared absorption and luminescent metal complexes [43-46]. They all follow the same design principle: Use the lone 
electron pair of $\mathrm{N}$ atom to coordinate with metal atoms with empty orbitals to obtain metal complexes.

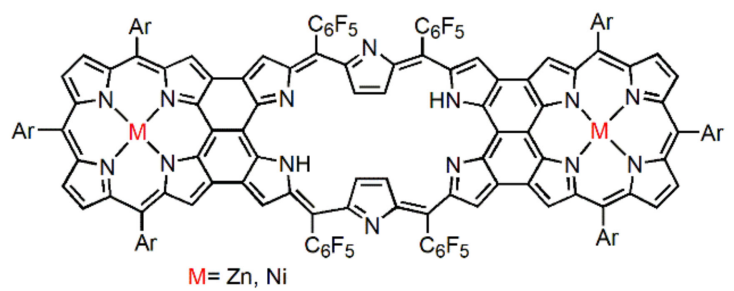

16

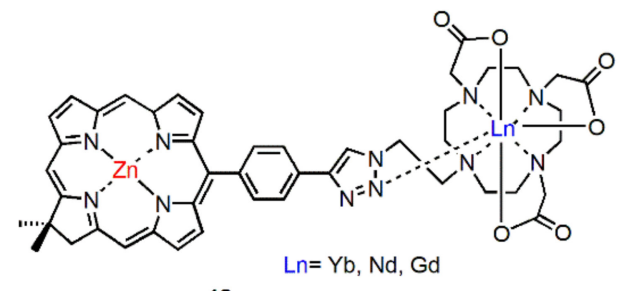

18

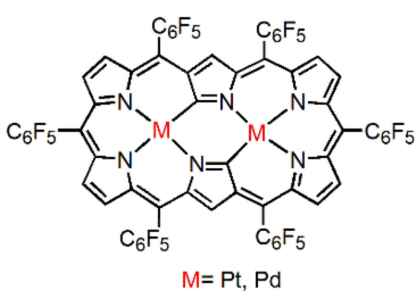

17

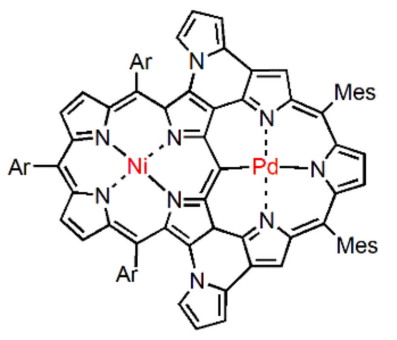

19

Figure 7. Chemical structure of some polypyrrole bridging ligands.

\subsection{Schiff Base Bridging Ligand}

Schiff bases are an important class of organic ligands with adjustable structures. The synthesis process of Schiff base is relatively simple, and its performances and structures are varied. Researchers meticulously designed and synthesized many kinds of Schiff base ligands containing functional groups, which aim to prepare structurally stable transition metal, non-transition metal, and rare earth metal complexes demonstrating potential application in luminescent materials.

In recent years, with the development of NIR luminescence materials, salicylaldehyde Schiff base derivatives with long alkyl chains have been widely used as bridged ligands in the synthesis of NIR complexes with bridging ligands [47-51]. These flexible ligands can exhibit various coordination modes with metal ions and have interesting structures and properties. For example, $\mathrm{Xu}$ et al. using $\beta$-diketonate $(\mathrm{DBM}=$ dibenzoylmethanide $)$ and Schiff base (20) designed and synthesized a series of lanthanide complexes with a dinuclear double-stranded helicate structure [47]. Among them, the luminescence spectra of complex $\mathrm{Yb}_{0.1} \mathrm{Gd}_{0.9} \mathrm{DBM}_{3}$ in the solid state were obtained at $193 \mathrm{~K}$, and the NIR emission bands of $\mathrm{Yb}^{3+}$ were detected and assigned at nearby $970 \mathrm{~nm}\left({ }^{2} \mathrm{~F}_{5 / 2}-{ }^{2} \mathrm{~F}_{7 / 2}\right)$, alongside the other broad bands centered at about $1020 \mathrm{~nm}$. Flexible ligands may provide more possibilities for constructing unique frameworks structures due to their freedom of conformation. However, there are few reports on the construction of multi-core d-f clusters by flexible ligands. Therefore, Yang et al. made compound $\mathbf{2 1}$ by modification of ligand $\mathbf{2 0}$ and applied it as a bridge to synthesize multinucleated lanthanide complexes with different multidentate ligands, which were capable of bonding two metal centers [48]. Their NIR luminescence properties were determined. The excitation of $\mathrm{Cd}-\mathrm{Ln}$ complexes $\left[\mathrm{Ln}_{8} \mathrm{Cd}_{24} \mathrm{~L}_{12}(\mathrm{OAc})_{48}\right]$ at 285 or $355 \mathrm{~nm}$ induced to the emission at $980 \mathrm{~nm}$ for the $\mathrm{Yb}$ complex and $890 \mathrm{~nm}$ and 1080 $\mathrm{nm}$ for the Nd complex.

Some d-block transition metal ions, such as $\mathrm{Zn}(\mathrm{II}), \mathrm{Ru}(\mathrm{II}), \mathrm{Pt}(\mathrm{II})$, and $\mathrm{Cd}(\mathrm{II})$, as metal chromomeres, not only have strong visible emission but can also be used as sensitizers for NIR lanthanide luminescence. Therefore, the design of suitable ligands to link them to realize the dual-emissive performance of visible ligand center emission and near-infrared lanthanide luminescence has aroused researchers' interest. Upon the above analysis, the longchain bis-salicyaldehyde Schiff base may be used as an antenna ligand to achieve this function. So Liu et al. employed ligand 22 as a bridge to link $\mathrm{Zn}$ (II) with $\mathrm{Nd}$ (III) to synthesize complex $\left[\mathrm{Zn}_{6} \mathrm{Nd}_{8} \mathrm{~L}_{2}(\mathrm{OAc})_{20}(\mathrm{O})_{2}\left(\mathrm{NO}_{3}\right)_{4}\left(-\mathrm{OC}_{2} \mathrm{H}_{5}\right)_{4}\right]$ [49]. $\left[\mathrm{Zn}_{6} \mathrm{Nd}_{8} \mathrm{~L}_{2}(\mathrm{OAc})_{20}(\mathrm{O})_{2}\left(\mathrm{NO}_{3}\right)_{4}(-\right.$ 
$\left.\left.\mathrm{OC}_{2} \mathrm{H}_{5}\right)_{4}\right]$ not only exhibited typical NIR luminescence of $\mathrm{Nd}^{3+}$ at $1061 \mathrm{~nm}\left({ }^{4} \mathrm{~F}_{3 / 2} \rightarrow{ }^{4} \mathrm{I}_{11 / 2}\right)$, but also the ligand-centered emission is found at $494 \mathrm{~nm}$. Furthermore, by increasing the length of alkyl chains, Liu and co-works designed compound $\mathbf{2 3}$ as a bridge to connect $\mathrm{Sm}(\mathrm{III})$ and prepared the homonuclear complex $\left[\mathrm{Sm}(\mathrm{HL})_{2}\left(\mathrm{NO}_{3}\right)\right]_{n}[50]$. Despite the absence of transition metal ions, $\left[\mathrm{Sm}(\mathrm{HL})_{2}\left(\mathrm{NO}_{3}\right)\right]_{n}$ still exhibited dual-emission performance. The excitation of $\left[\mathrm{Sm}(\mathrm{HL})_{2}\left(\mathrm{NO}_{3}\right)\right]_{n}$ at $365 \mathrm{~nm}$ induced the emission at $649 \mathrm{~nm}$ $\left({ }^{4} \mathrm{G}_{5 / 2} \rightarrow{ }^{6} \mathrm{H}_{9 / 2}\right)$ and $959 \mathrm{~nm}\left({ }^{4} \mathrm{G}_{5 / 2} \rightarrow{ }^{6} \mathrm{~F}_{5 / 2}\right)$, respectively. Meanwhile, the ligand-centered emission is found at $465 \mathrm{~nm}$.

Salen-type Schiff base is a kind of commonly used organic ligand, which is chelating ligand formed by the condensation of two identical salicylaldehyde molecules and a diamine molecule. There are 4 atoms of $\mathrm{O}, \mathrm{N}, \mathrm{N}$, and $\mathrm{O}$ in the center, which can be used as ligand units of some metal ions to form M-salen complexes $(\mathrm{M}=\mathrm{Ti}, \mathrm{Zr}, \mathrm{Fe}, \mathrm{Mn}, \mathrm{Co}$, $\mathrm{Zn}$, etc.). Interestingly, 3-Methoxysalicylaldehyde react with different diamine derivatives can generate an additional coordination cavity for coordinating with other metal ions (usually lanthanides) to form dinuclear complexes, which are usually used to study the luminescence properties of 3d-4f heterometallic Schiff base complexes [52-55]. For example, complexes 24-26 in Figure 8 all exhibit excellent luminescence performance in the NIR region. Inspired by salen-type Schiff base, some ligands that mimic the coordination pattern of salen-type Schiff bases were synthesized. Refs. [56,57], such as complexes $\mathbf{2 7}$ and $\mathbf{2 8}$, they have the same coordination mode as salen-type Schiff base. These metal complexes with these synthesized bridging ligands also show good near-infrared luminescence properties.<smiles>Oc1ccccc1/C=N/CCCCCC/N=C/c1ccccc1O</smiles><smiles>COc1cccc(/C=N/CCCCCC/N=C/c2cccc(OC)c2O)c1O</smiles>

21<smiles>COc1cccc(/C=N/CCOCCOCC/N=C/c2cccc(OC)c2O)c1O</smiles>

22<smiles>Oc1c(Cl)cc(Cl)cc1/C=N/CCCCCCCCCC/N=C/c1cc(Cl)cc(Cl)c1O</smiles>

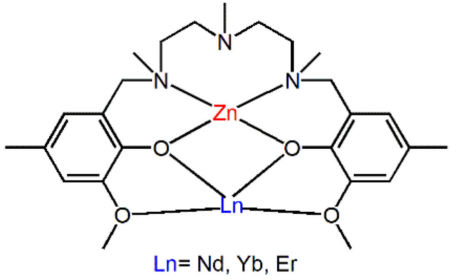

27

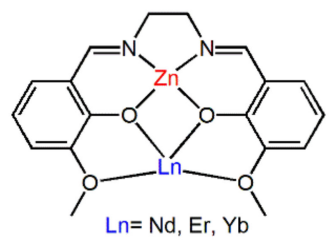

24

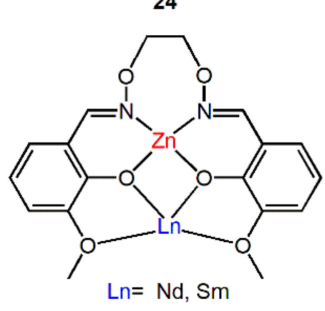

25
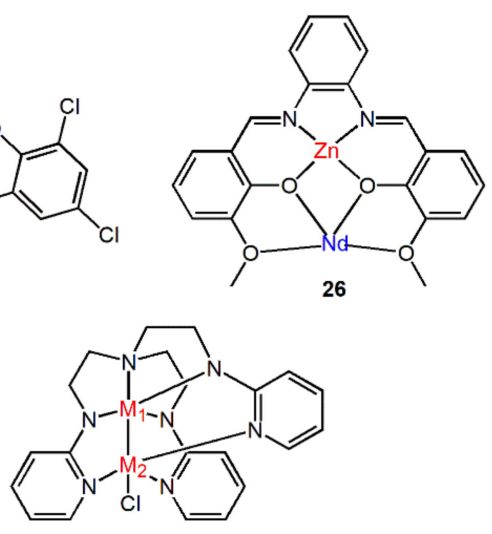

$\mathrm{M}_{1}=\mathrm{Co}, \mathrm{Fe} \cdot \mathrm{M}_{2}=\mathrm{Co}, \mathrm{Fe}, \mathrm{Mn}$

28

Figure 8. Some Schiff base bridging ligands and complexes mentioned in this section. 


\subsection{Carboxyl Bridging Ligand}

Carboxyl group, the oxygen-containing functional group, occupies an important position in coordination chemistry because it has abundant coordination patterns and can form stable complexes. In the study of NIR light-emitting complexes with bridging ligands, carboxyl compounds are also a very important type of bridging ligand, and a large number of complexes using carboxyl groups for bridging have been synthesized [14,52,58-63]. Usually, the metal atoms involved in the coordination and the carboxyl group form coordination bonds in the same plane. The coordination modes can be roughly divided into three categories, i.e., monodentate coordination, chelation coordination, and bridge coordination (Figure 9). However, this does not mean that they exist independently or oppositely. Sometimes in a polycarboxyl ligand, two or three coordination modes can be found to exist simultaneously.

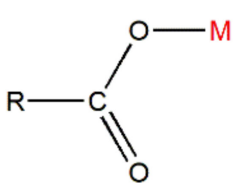

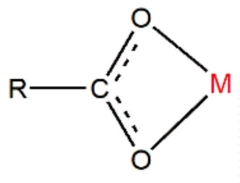

b<smiles></smiles>

c

Figure 9. The coordination pattern of carboxyl group: (a) Monodentate coordination; (b) chelation coordination; (c) bridge coordination.

It can be found from the above analysis that ligands with a single carboxyl group can also be used as bridging ligands to prepare metal complexes. However, in the preparation of most complexes, researchers tend to use polycarboxyl organic ligands which can link multiple metal centers for the synthesis of complexes with bridging ligands. Ethylene Diamine Tetraacetic Acid (EDTA) (Figure 10, 29), as a representative chelating agent, is an early polycarboxylic organic ligand. It can form a stable water-soluble complex with alkali metals, rare earth elements, and transition metals and has a wide range of applications in life [64-67]. Nevertheless, with the development of coordination chemistry research, fatty acid ligands have been unable to meet the demands of researchers, so a large number of aromatic acids began to be used in the synthesis of complexes. Among them, $p$-phthalic acid (Figure 10,30) has perfect geometric symmetry and diverse coordination modes and is a commonly used polycarboxyl ligand. It is also found that $p$-phthalic acid is often used as an auxiliary bridged ligand in NIR luminescence complexes. For example, Lü group and Dong group used $p$-phthalic acid as an auxiliary ligand to self-assemble with the salen-type Schiff base binuclear complex, and obtained multinuclear NIR luminescent complexes with bridging ligands $[52,63]$. Their crystal structures were shown in Figure 11. Among them, complexes C-2, C-3, and C-4 exhibited similar absorption spectra in the UV-visible region $\left(\lambda_{\max }=203,230,267\right.$, and $348 \mathrm{~nm}$ ), showing a redshift compared to the ligand (e.g., salen-type Schiff base) $\left(\lambda_{\max }=248,337 \mathrm{~nm}\right)$. In addition, the NIR emission spectra of these three complexes in $\mathrm{MeOH}$ at room temperature were obtained. The results showed that they exhibited excellent NIR emissive properties at 863,1060, and $1328 \mathrm{~nm}$, which are typical emission of $\mathrm{Nd}^{3+}$ originating from the ${ }^{4} \mathrm{~F}_{3 / 2} \rightarrow{ }^{4} \mathrm{I}_{9 / 2},{ }^{4} \mathrm{~F}_{3 / 2} \rightarrow{ }^{4} \mathrm{I}_{11 / 2}$, and ${ }^{4} \mathrm{~F}_{3 / 2} \rightarrow{ }^{4} \mathrm{I}_{13 / 2}$ transitions, respectively. Other small-molecule polycarboxylic compounds, such as 0 phthalic acid (Figure 10, 31), m-phthalic acid (Figure 10, 32), and trimesic acid (Figure 10, 33), are commonly used bridging ligands. 
<smiles>O=C(O)CN(CCN(CC(=O)O)CC(=O)O)CC(=O)O</smiles>

29<smiles>O=C(O)c1ccc(C(=O)O)cc1</smiles>

30<smiles>O=C(O)c1ccccc1C(=O)O</smiles>

o-Phthalic<smiles>O=C(O)c1cccc(C(=O)O)c1</smiles>

32<smiles>O=C(O)c1cc(C(=O)O)cc(C(=O)O)c1</smiles>

33<smiles>O=C(O)c1ccc(C(=O)O)c(S(O)(O)O)c1</smiles><smiles>O=C(O)c1c(F)c(F)c(F)c(F)c1C(=O)O</smiles><smiles>O=C(O)c1ccc(CN(Cc2ccc(C(=O)O)cc2)Cc2cc(C(=O)O)cc(C(=O)O)c2)cc1</smiles><smiles>Cc1c(C)c(C(=O)O)c(C)c2c1Cc1c(C)c(C(=O)O)c(C)c3c1B2c1c(C)c(C)c(C(=O)O)c(C)c1C3</smiles>

37
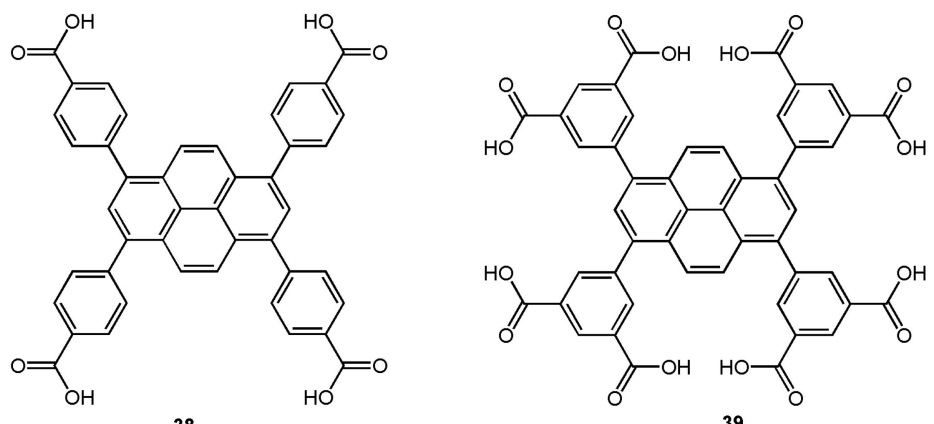

39

Figure 10. Some polycarboxyl compounds which can be used as bridged ligands mentioned in this chapter.

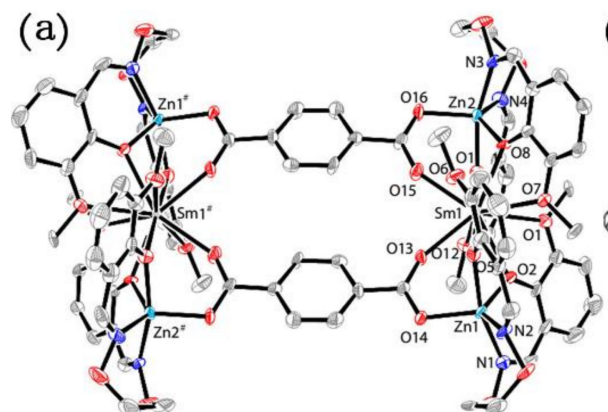

C-1

(c)

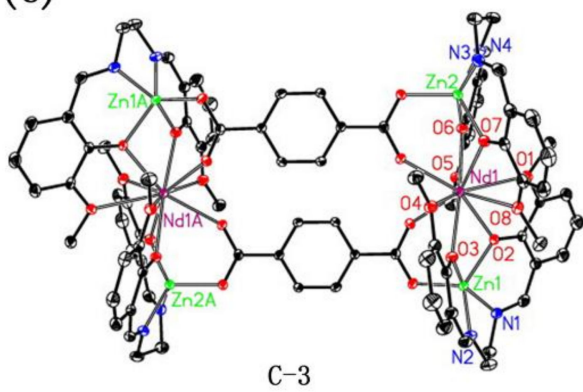

(b)

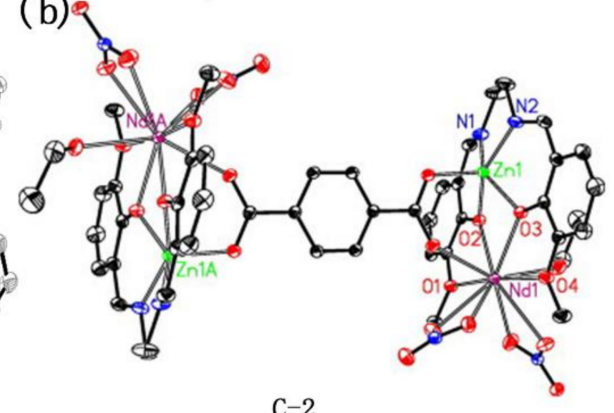

C-2

(d)

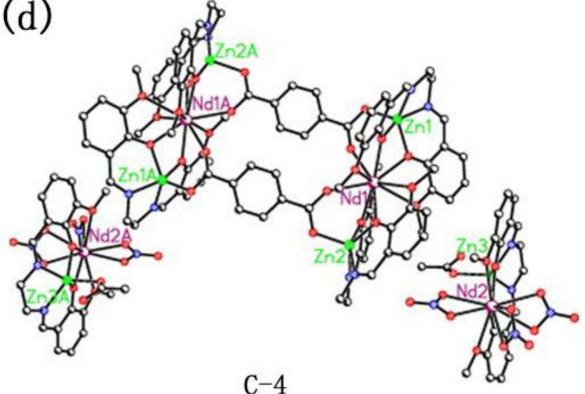

Figure 11. A view of the molecular structures of complexes (a) C-1; (b) C-2; (c) C-3; (d) C-4. (a) Reprinted with permission from [52]. Copyright 2016, American Chemical Society; (b-d) Reprinted from [63]. Copyright 2009, with permission from Elsevier. 
However, the metal complexes with polycarboxyl compounds as ligands are easy to form coordination polymers and metal-organic frameworks (MOFs) because of the super coordination ability of carboxyl oxygen atoms [58,60-62]. For instance, Erkarslan group and Feng group synthesized 1D chain polymer with near-infrared luminescence using modified polycarboxylic acid compounds 34 and 35 (Figure 10) in coordination with lanthanide ions, respectively (Figure 12) [60,62]. To obtain coordination compounds with better photophysical and photochemical properties, some functional groups with specific functions are introduced into organic ligands, e.g., from compound $\mathbf{3 6}$ to compound $\mathbf{3 9}$ (Figure 10), tertiary amino group, boron, and pyrene group were introduced, respectively, and they all fulfilled specific functions $[14,59,61]$. However, they still use carboxyl groups for coordination and the molecule contains multiple carboxyl groups, so these complexes are mainly polymers.
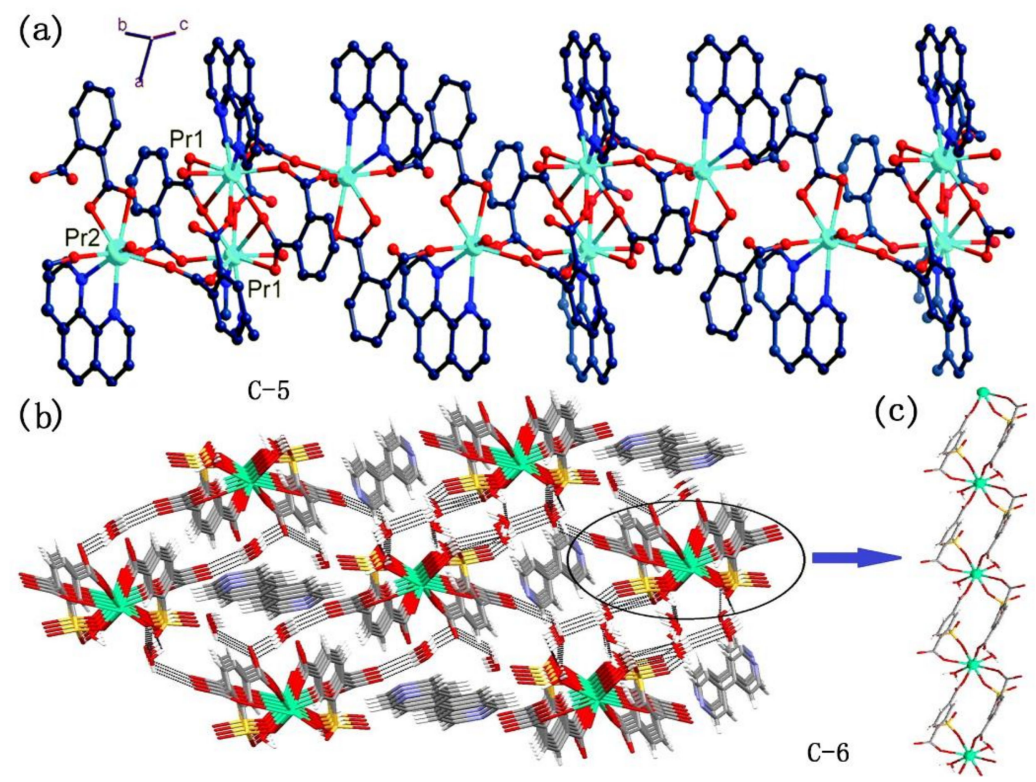

Figure 12. (a) A view of the molecular structure of complexes C-5; (b) a view of 3-D hydrogen bond network of C-6 in bc plane. Uncoordinated 4,40-bipyridine molecules occupy the channels; (c) a view of 1-D infinite chain along $a$ axis constructed by C-6. (a) Reprinted with permission from [60], Copyright 2019, Feng, X. et al. (b,c) Reprinted from [62], Copyright 2016, with permission from Elsevier.

The photophysical data of some complexes which were mentioned in this section were summarized in Table 1 below.

Table 1. Photophysical data for some complexes that were mentioned in this chapter.

\begin{tabular}{|c|c|c|c|c|}
\hline Complex & Medium & $\lambda_{\mathrm{abs}}(\mathrm{nm})$ & $\lambda_{\text {ex }}(\mathrm{nm})$ & $\lambda_{\text {em }}(\mathrm{nm})$ \\
\hline$\left[\mathrm{Zn}_{2} \mathrm{Nd}_{2} \mathrm{~L}_{2}-\left(4,4^{\prime}-\mathrm{bpy}\right)\left(\mathrm{NO}_{3}\right)_{6}\right] \cdot \mathrm{Et}_{2} \mathrm{O}$ & $\mathrm{MeOH}$ & $204,228,271,348$ & 337 & \multirow{6}{*}{$\begin{array}{c}863,1060,1328 \\
\text { 863, 1060, 1328 } \\
\text { Ln = Yb, 975; } \\
=\mathrm{Nd}, 866,1060,1330 ; \\
=\mathrm{Er}, 1534 \\
\text { 866, 1061, 1330; } \\
\mathrm{Ln}=\mathrm{Yb}, 976 ; \\
=\mathrm{Pr}, 1030 ; \\
=\mathrm{Er}, 1531 ; \\
785\end{array}$} \\
\hline$\left[\mathrm{Zn}_{2} \mathrm{Nd}_{2} \mathrm{~L}_{2}\left(4,4^{\prime}-\mathrm{bpe}\right)\right] \cdot 2 \mathrm{H}_{2} \mathrm{O}$ & $\mathrm{MeOH}$ & $204,228,271,348$ & 337 & \\
\hline$\left[\operatorname{Re}(\mathrm{CO})_{3} \mathrm{Cl}(\mu\right.$-bpm $\left.) \operatorname{Ln}(\text { fod })_{3}\right]$ & $\mathrm{CH}_{2} \mathrm{Cl}_{2}$ & $>400$ & 460 & \\
\hline$\left[\left(\mathrm{F}_{3} \mathrm{C}-\mathrm{C}_{6} \mathrm{H}_{4}-\mathrm{CC}\right)_{2} \mathrm{Pt}(\mu-\mathrm{bpm}) \mathrm{Nd}(\mathrm{hfac})_{3}\right]$ & $\mathrm{CH}_{2} \mathrm{Cl}_{2}$ & $>400$ & 460 & \\
\hline $\mathrm{Ln}_{2}(\mathrm{HTH})_{6} \mathrm{bpm}$ & $\mathrm{CH}_{2} \mathrm{Cl}_{2}$ & - & 378 & \\
\hline 11 & DMSO & 291,397 & 445 & \\
\hline 12 & $\mathrm{MeOH}$ & - & 529 & $\begin{array}{l}\mathrm{Ln}=\mathrm{Yb}, 980 \\
=\mathrm{Nd}, 870,1064\end{array}$ \\
\hline 15 & $\mathrm{MeOH}$ & - & 590 & $\begin{array}{l}\mathrm{Ln}=\mathrm{Yb}, 980 \\
=\mathrm{Nd}, 890,1064\end{array}$ \\
\hline
\end{tabular}


Table 1. Cont

\begin{tabular}{ccccc}
\hline Complex & Medium & $\lambda_{\text {abs }}(\mathbf{n m})$ & $\lambda_{\text {ex }}(\mathbf{n m})$ & $\lambda_{\text {em }}(\mathbf{n m})$ \\
\hline $\mathrm{Yb}_{0.1} \mathrm{Gd}_{0 .} \mathrm{DBM}_{3}$ & Solid & $225,252,321,400$ & 296 & 970,1020 \\
{$\left[\mathrm{Ln}_{8} \mathrm{Cd}_{24} \mathrm{~L}_{12}(\mathrm{OAc})_{48}\right]$} & $\mathrm{CH}{ }_{3} \mathrm{CN}$ & $226,270,350$ & 298,355 & $\mathrm{Ln}=\mathrm{Yb}, 980 ;$ \\
$=\mathrm{Nd}, 890,1080$ & 1061 \\
{$\left[\mathrm{Zn}_{6} \mathrm{Nd}_{8} \mathrm{~L}_{2}(\mathrm{OAc})_{20}(\mathrm{O})_{2}\left(\mathrm{NO}_{3}\right)_{4}\left(-\mathrm{OC}_{2} \mathrm{H}_{5}\right)_{4}\right]$} & $\mathrm{CH}_{3} \mathrm{CN}$ & 355 & 355 & $917,959,1043,1196$ \\
{$\left[\mathrm{Sm}(\mathrm{HL})_{2}\left(\mathrm{NO}_{3}\right)\right]_{\mathrm{n}}$} & $\mathrm{DMF}$ & $255,278,332,424$ & 365 & $874,903,1059,1339$ \\
$\mathrm{C}-1$ & $\mathrm{MeOH}$ & 350 & 350 & 1026 \\
$\mathrm{C}-5$ & Solid & - & 376 & 840,960 \\
$\mathrm{C}-6$ & Solid & - & 349 & \\
\hline
\end{tabular}

\section{Application}

NIR light-emitting metal complexes display unique potential applications in electroluminescence, magnetism, chemosensors, optical telecommunication, and bioimaging. Most of the above-mentioned research on complexes with bridging ligands is based on their near-infrared luminescence properties [68-74]. Herein, NIR light-emitting metal complexes with bridging ligands in different fields of applications are introduced below.

\subsection{Electroluminescence}

Organic light-emitting diodes (OLEDs) have been widely used in displays and lighting production [75,76]. Many corresponding red, green, and blue (RGB) emitters have passed rigorous industrial evaluations for commercial applications. However, the development of NIR emitting material prepared OLED devices with emission wavelengths exceeding $700 \mathrm{~nm}$ is relatively lagging and still in the exploratory stage [77-79]. To promote the application of NIR emission complexes with bridging ligands in OLED, some researchers have made great contributions [80].

As shown in Figure 13, Su et al. designed and synthesized two NIR emitting binuclear platinum(II) complexes bridged by ancillary ligand of 3,5-dimethyl pyrazol (dmpz), in which 2-(pyren-1-yl) pyridine (pypy) and its derivative of 2-(7-(tert-butyl)pyren-1yl)pyridine ( ${ }^{t}$ Bupypy) were used as cyclometalated ligands, respectively [81]. The authors further investigated their photophysical and electroluminescent properties. These results showed that the intrinsic NIR electroluminescent (EL) emission peak at $692 \mathrm{~nm}$ with a shoulder at $753 \mathrm{~nm}$ was observed in both the single-emissive-layer polymer light-emitting diodes (PLED) doping binuclear platinum(II) complexes. Interestingly, their external quantum efficiency (EQE) changed inversely with the increase of doping concentration. The (pypy) ${ }_{2} \mathrm{Pt}_{2}(\mathrm{dmpz})_{2}$-based devices exhibited a decreased EL efficiency with increasing dopant concentrations from $2 \mathrm{wt} \%$ to $8 \mathrm{wt} \%$, while the ( $\left.{ }^{t} \mathrm{Bupypy}\right)_{2} \mathrm{Pt}_{2}(\mathrm{dmpz})_{2}$-based devices displayed an increased EL efficiency. Unfortunately, neither of them showed high EQE. The highest EQE values of $0.11 \%$ and $0.15 \%$ were obtained in the (pypy $)_{2} \mathrm{Pt}_{2}\left(\mathrm{dmpz}_{2}\right)^{-}$ and ( ${ }^{t}$ Bupypy $)_{2} \mathrm{Pt}_{2}(\mathrm{dmpz})_{2}$-based devices, respectively. 

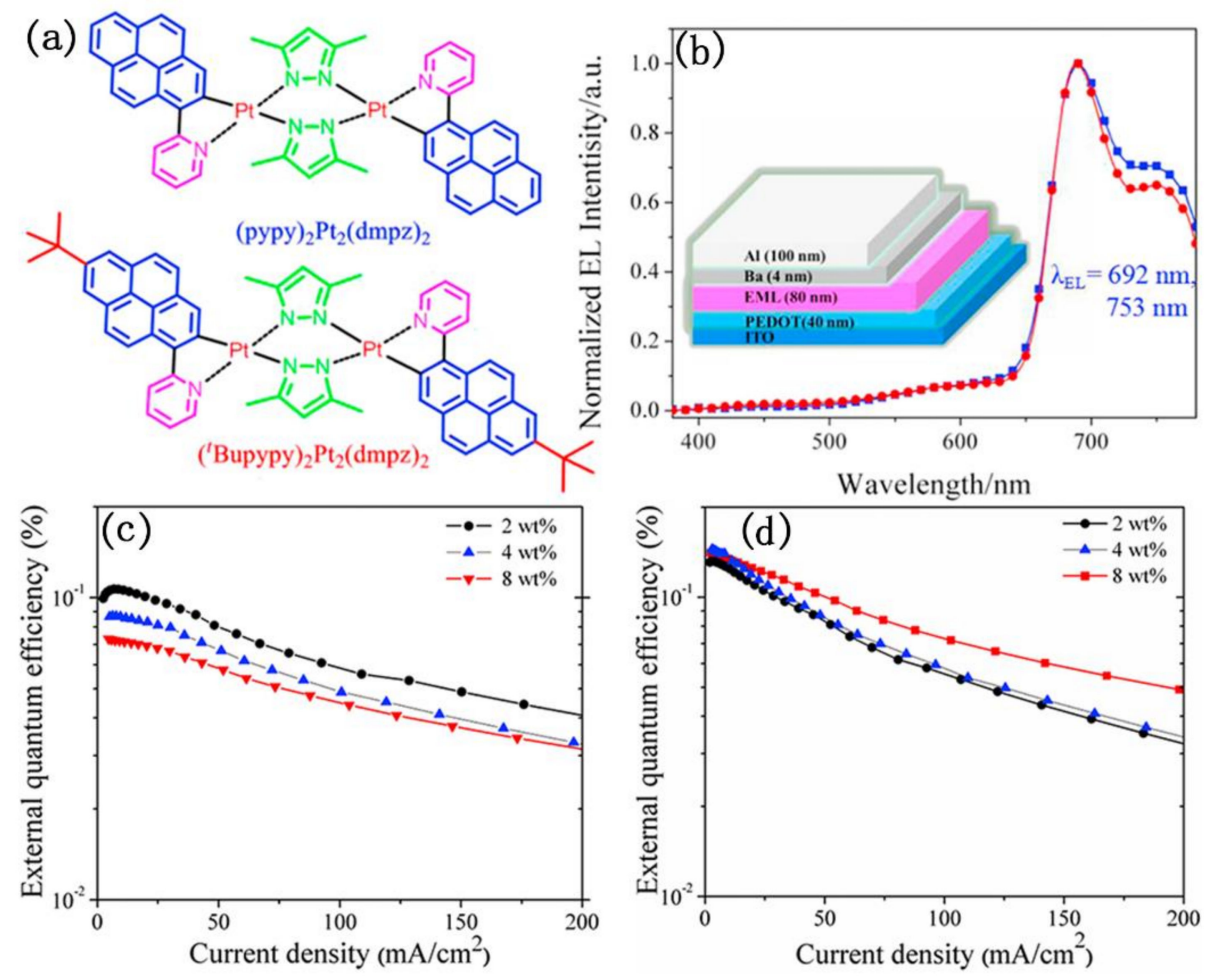

Figure 13. (a) The structure of (pypy) ${ }_{2} \mathrm{Pt}_{2}(\mathrm{dmpz})_{2}$ and $\left({ }^{t} \mathrm{Bupypy}\right)_{2} \mathrm{Pt}_{2}(\mathrm{dmpz})_{2} ;(\mathbf{b})$ electroluminescent (EL) spectra of the of (pypy $)_{2} \mathrm{Pt}_{2}(\mathrm{dmpz})_{2}$ and ( ${ }^{t}$ Bupypy $)_{2} \mathrm{Pt}_{2}(\mathrm{dmpz})_{2}$-based devices. Inset: The diagram of the EL devices; (c,d) are the external quantum efficiency (EQE) curves of the (pypy) ${ }_{2} \mathrm{Pt}_{2}(\mathrm{dmpz})_{2}$ - and $\left({ }^{t} \mathrm{Bupypy}\right)_{2} \mathrm{Pt}_{2}(\mathrm{dmpz})_{2}$-based devices at different dopant concentrations from $2 \mathrm{wt} \%$ to $8 \mathrm{wt} \%$. Reprinted from [81], Copyright 2016, with permission from Elsevier.

External quantum efficiency is an important factor in the evaluation of electroluminescent devices, only materials with high EQE can be commercialized. In order to improve the luminescence ability of platinum(II) complexes, $\mathrm{Wu}$ and co-workers reported a novel NIR-emitting binuclear platinum complex (piq $)_{2} \mathrm{Pt}_{2}\left(\mu-\mathrm{C}_{8} \mathrm{OXT}\right)_{2}$, in which piq is 1-phenylisoquinolinato (piq) and $\mathrm{C}_{8} \mathrm{OXT}$ is a bridging ancillary ligand of 5-(4octyloxyphenyl)-1,3,4-oxadiazole)-2-thiol ( $\mathrm{C}_{8} \mathrm{OXT}$ ) [82]. As shown in Figure 14, the study about photo-physical, electrochemical, and electroluminescent characteristics revealed that binuclear platinum complex exhibited an intense absorption peak at about $493 \mathrm{~nm}$ from the metal-metal-to-ligand charge transfer transition (MMLCT) and a bright near-infrared emission at $721 \mathrm{~nm}$ in chloromethane. In the EL spectra, a NIR emission with a maximum peak at $706 \mathrm{~nm}$ and CIE coordinates $(0.68,0.31)$ were observed at different dopant concentrations from $1 \mathrm{wt} \%$ to $8 \mathrm{wt} \%$ for these devices under electric field. Whereas, the external quantum efficiency (EQE) changed from $2.7 \%$ to $6.3 \%$ at $7.6 \mathrm{~mA} \mathrm{~cm}^{-2}$ as the concentrations of (piq) $)_{2} \mathrm{Pt}_{2}\left(\mu-\mathrm{C}_{8} \mathrm{OXT}\right)_{2}$ in PFO-PBD film increased. Thus, the highly efficient NIR emission was realized from the binuclear platinum(II) complex in PLEDs.

Recently, non-doped OLED devices in which NIR emissive complexes with bridging ligands with electroluminescence properties are directly used as light-emitting layers have attracted attention. In 2019, Wang and co-workers synthesized a series of diplatinum(II) complexes with the molecular formula $\left[\mathrm{Pt}(\mathrm{pypm})\left(\mu-\mathrm{F}^{\mathrm{n}}\right)\right]_{2}$ bearing a pyridine-pyrimidinate (pypm) chelate and a formamidinate bridge (Figure 15), in which (pypm) $\mathrm{H}$ and $\mathrm{F}^{\mathrm{n}} \mathrm{H}$ stand for 5-(pyridin-2-yl)-2-(trifluoromethyl)pyrimidine and functional formamidines with various substituents of $\mathrm{Ph}(\mathrm{n}=2)(40 \mathrm{a}), \mathrm{C}_{6} \mathrm{H}_{4}{ }^{t} \mathrm{Bu}(\mathrm{n}=3)(40 \mathrm{~b})$, and $\mathrm{C}_{6} \mathrm{H}_{4} \mathrm{CF}_{3}(\mathrm{n}=4)$ (40c) [77]. 40b was selected as a non-doped emitter for the fabrication of NIR-emitting OLEDs. An electroluminescence NIR peak was observed at $767 \mathrm{~nm}$ in EL spectra and the maximum EQE value of $0.14 \%$ was obtained in the OLED device. Although the EQE value is too low or even negligible, it has realized the progress of the NIR light-emitting 
complexes with bridging ligands as a light-emitting layer from being a dopant to the pure substance.

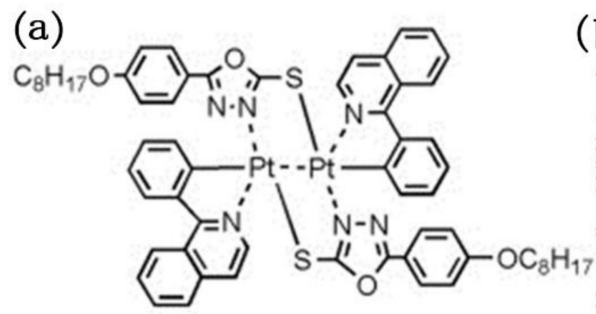

(piq) $\mathrm{Pt}\left(\mu-\mathrm{C}_{8} \mathrm{OXT}\right)_{2} \mathrm{Pt}($ piq)

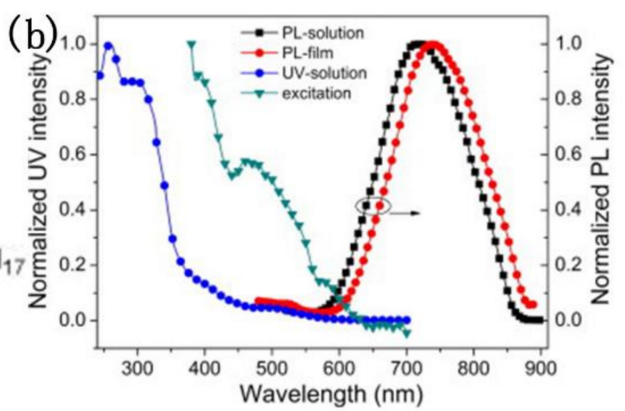

(d) 7
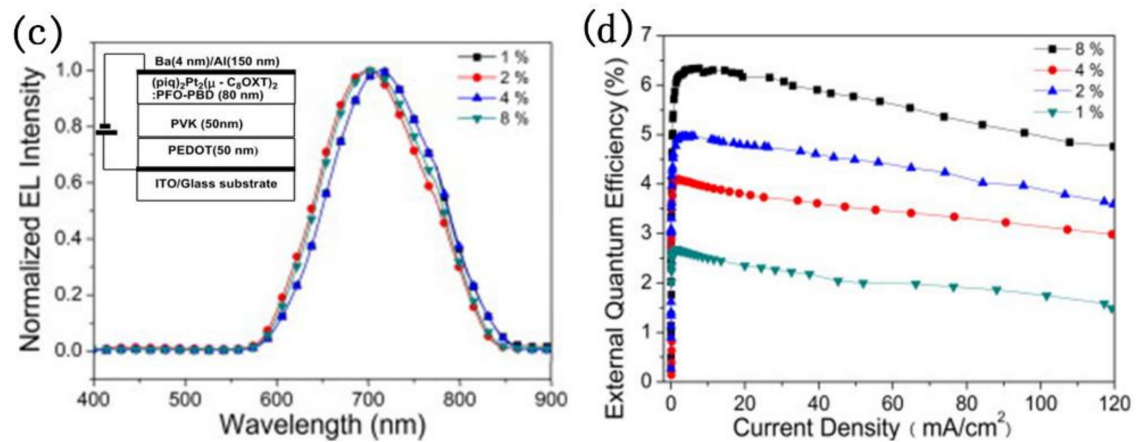

Figure 14. (a) The structure of (piq) $)_{2} \mathrm{Pt}_{2}\left(\mu-\mathrm{C}_{8} \mathrm{OXT}\right)_{2} ;$ (b) Absorption and PL spectra of (piq) $)_{2} \mathrm{Pt}_{2}(\mu-$ $\left.\mathrm{C}_{8} \mathrm{OXT}\right)_{2} ;$ (c) EL spectra and (d) EQE curves of the (piq) $)_{2} \mathrm{Pt}_{2}\left(\mu-\mathrm{C}_{8} \mathrm{OXT}\right)_{2}$-doped PFO-PBD devices with different dopant concentrations. Insert: (c) The diagram of the EL devices. Reprinted from [82]. Copyright 2012, with permission from Elsevier.

(a)

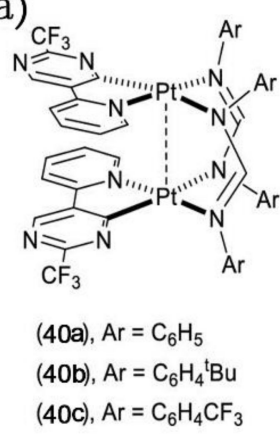

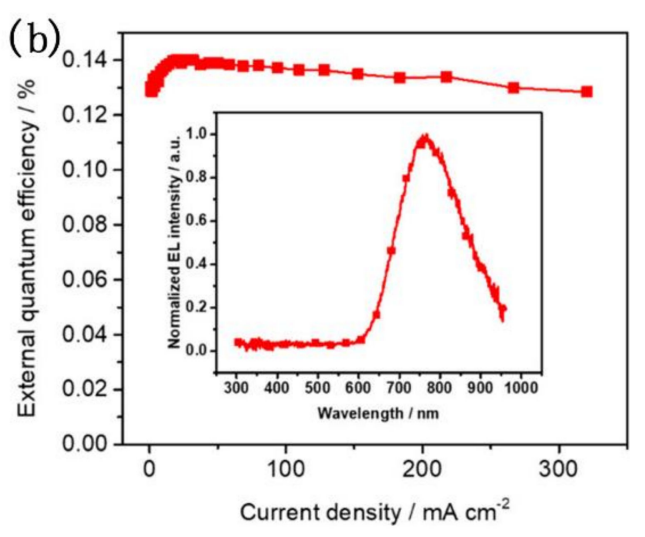

Figure 15. (a) The structure of 40a-40c; (b) EQE curves of organic light-emitting diodes (OLED) with $40 \mathrm{~b}$ as the non-doped emitter. Inset: EL spectra of OLED. Reprinted with permission from [77]. Copyright 2019, American Chemical Society.

To improve the luminescence efficiency of pure dinuclear platinum complexes as lightemitting layers in OLED devices, Chou's group strategically designed and synthesized a new series of dinuclear platinum(III) complexes, namely Pt2a-Pt2c (Figure 16) [83]. The donor (D)-acceptor (A)-type oxadiazole-thiol was used as bridging ligands to chelate with $\mathrm{Pt}(\mathrm{III})$. Although dinuclear platinum(III) complexes were usually reported to have short-lived lowest-lying triplet states, which is harmful to photoluminescence, they possess a $d^{7}-d^{7}$ electronic configuration and exhibit intense phosphorescence under ambient conditions. Photo-physical and photo-chemical study showed that Pt2a exhibited orange phosphorescence $\left(\lambda_{\max }=618 \mathrm{~nm}\right)$ in degassed dichloromethane solution $\left(\Phi_{\mathrm{p}} \approx 8.2 \%, \tau_{\mathrm{p}}\right.$ 
$\approx 0.10 \mu \mathrm{s})$ and near-infrared (NIR) emission $\left(\lambda_{\max }=749 \mathrm{~nm}\right)\left(\Phi_{\mathrm{p}} \approx 10.1 \% \tau_{\mathrm{p}} \approx 0.66 \mu \mathrm{s}\right)$ in the crystalline powder. Pt2a was employed as a non-doped emitter to fabricate highperformance organic light-emitting diodes (OLEDs). The electroluminescence property study that the device had a strong NIR emission peak at $716 \mathrm{~nm}$ under electric field, and achieved an EQE value of 5.1\%. Importantly, the efficiency roll-off of the device was perfectly controlled and retains $3.8 \%$ of the EQE even at a high current density of $100 \mathrm{~mA}$ $\mathrm{cm}^{-2}$. Authors also studied Pt2a as a dopant (in $\mathrm{mCP}$ ) to fabricate OLED device. Although the device did not exhibit NIR electroluminescence performance (the maximum EL peak blue shift from $716 \mathrm{~nm}$ to $614 \mathrm{~nm}$ ), its EQE was improved from $5.1 \%$ to $8.7 \%$.
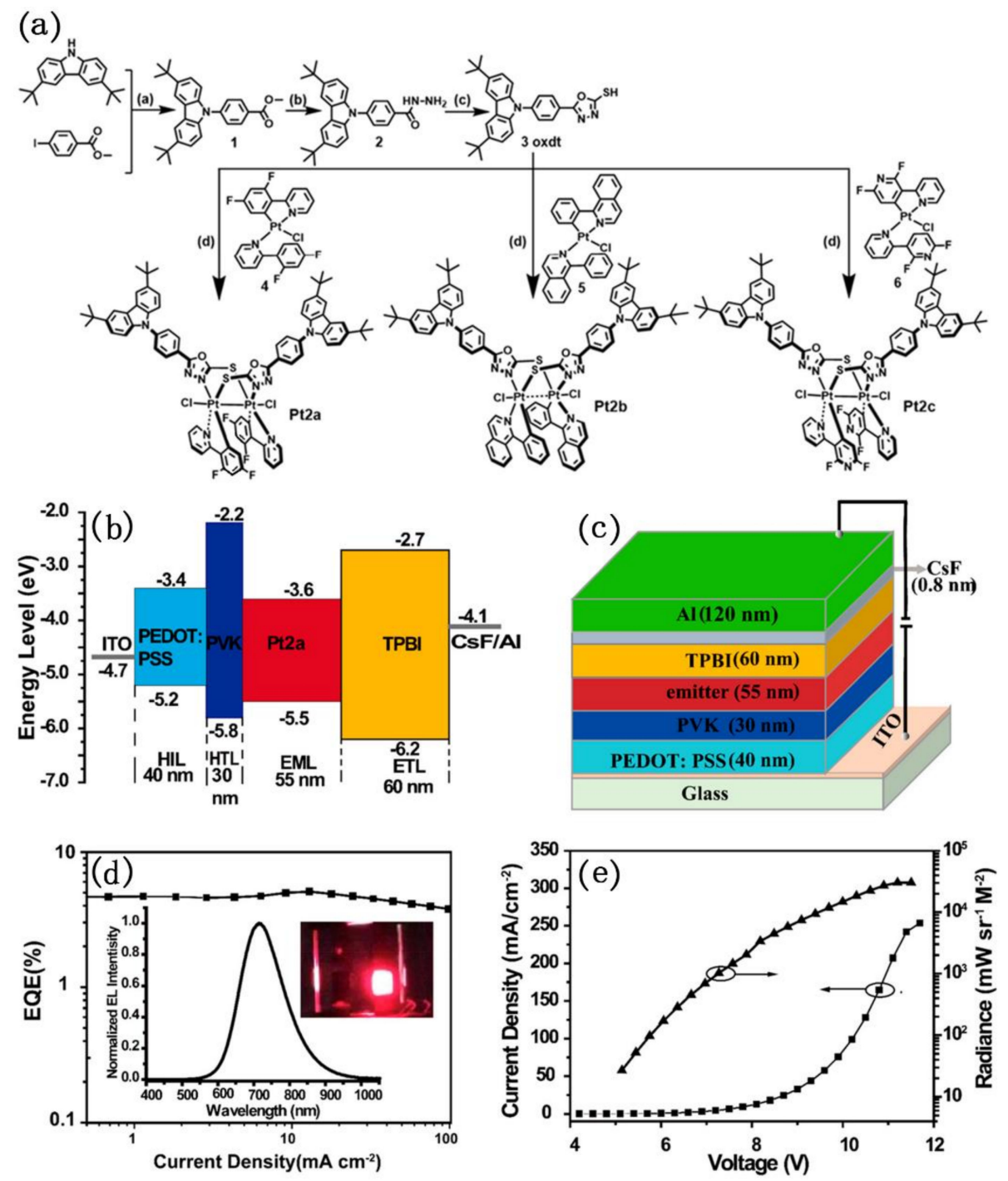

Figure 16. (a) The synthetic route of Pt2a-Pt2c; (b) energy-level diagrams, and (c) configuration of the device; (d) EQE curves of the device. Insets: EL spectra and a photograph of thebdevice in operation. (e) Current density-voltage-radiance $(\mathrm{J}-\mathrm{V}-\mathrm{R})$ curve of the device. Reprinted with permission from [83]. Copyright 2020, American Chemical Society.

\subsection{Biosensing/Bioimaging}

Compared with visible fluorescence imaging, NIR fluorescence imaging possesses unique advantages including low background, deep penetration, and minimal damage to biological tissues, and has extensive applications in biosensing and bioimaging [84-87]. The NIR emissive metal complexes with bridging ligands also show excellent performance in the biosensing/bioimaging field [88-92]. 
In 2018, Yang et al. found that many fluorescent pyrophosphate (PPi) sensors were developed with emission changes in the visible region, while NIR emissive sensors for PPi were rather scarce [91]. Thereupon, they designed and prepared a dicyanomethylenebenzopyran (DCMB) based phenol-bridged dinuclear Zn(II)-DPA (DPA: Dipicolylamine) complex (1-2Zn) which was found to be a promising NIR fluorescent sensor for PPi. The photo-physical study showed that 1-2Zn had a large Stokes shift (>150 nm) and exhibits unusual NIR fluorescence changes for PPi. Interestingly, upon addition of PPi with increasing amounts from 0 to 0.5 equiv., this emission band decreased gradually and almost linearly, and red-shifted to $654 \mathrm{~nm}$. Whereas, when PPi concentration was further increased, significant NIR fluorescence enhancement was observed at $654 \mathrm{~nm}$. In addition, the authors investigated the potential bioimaging applications of sensor 1-2Zn. As shown in Figure 17, the cells were incubated with PPi and 1-2Zn for $30 \mathrm{~min}$ at $37^{\circ} \mathrm{C}$, and a remarkable increase of intracellular fluorescence was observed. The result demonstrated that $1-2 Z n$ had great potential for imaging of PPi in living cells. 1-2Zn sensor in vivo detection of PPi experiment was also carried out. The fluorescence showed obvious enhancement when injection of PPi (1 or 2 eq) to the mouse and incubation with 1-2Zn were conducted, indicating 1-2Zn exhibited the excellent performance to the detection of PPi in vivo.

(a)
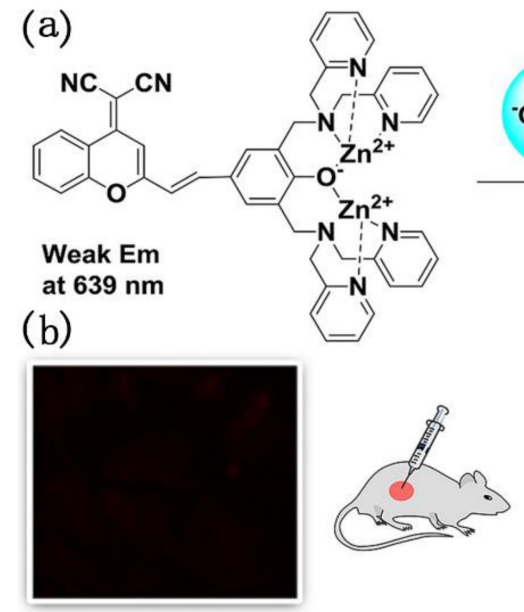
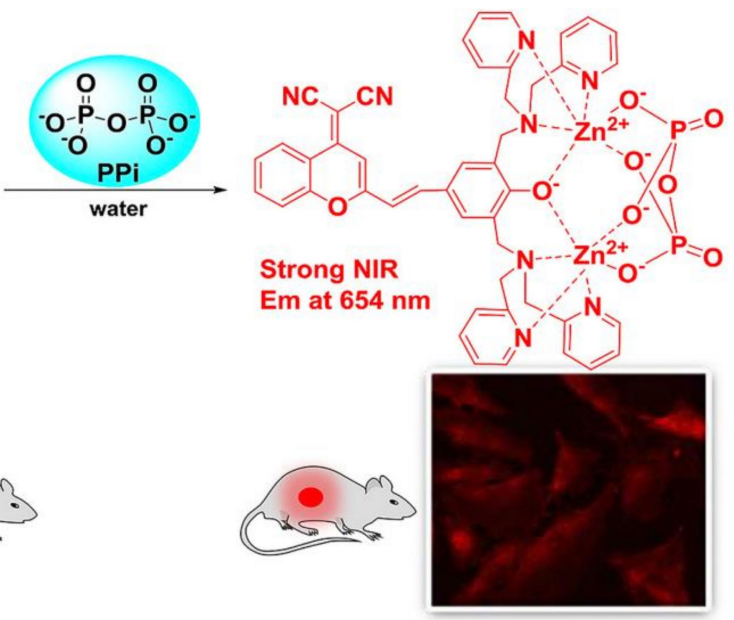

Figure 17. (a) The responsive mechanism of sensor 1-2Zn for PPi sensing; (b) fluorescent images of PPi in cell and mice with sensor 1-2Zn. Reprinted from [91], Copyright 2018, with permission from Elsevier.

Unlike the above-mentioned complexes that emit from organic ligands, NIR luminescent bridging complexes with central metal ions emission have also been studied and applied to cell imaging. For example, Crowston and co-workers used these N-heterocyclic ligands to connect metal ions to prepare a series of $\mathbf{R u} \cdot \mathbf{M}$ and $\mathbf{R u} \cdot \mathbf{M}_{\mathbf{2}}$ complexes, which were evaluated for their photophysical and cell imaging properties [92]. Among them, $\mathbf{R u} \cdot \mathbf{G d}$ and $\mathbf{R u} \cdot \mathbf{G d}_{\mathbf{2}}$ were observed with strong emission peaks at $664 \mathrm{~nm}$ and $700 \mathrm{~nm}$, respectively, and then were employed as the fluorescent sensor to use for cellular imaging. As shown in Figure 18, Live HeLa cells were initially incubated with either of these complexes at concentrations of $25 \mu \mathrm{M}, 50 \mu \mathrm{M}$, and $75 \mu \mathrm{M}$ for six or sixteen hours. The emission images of HeLa cells after incubation showed punctate cytoplasmic staining, indicating that both of the probes localized in a specific organelle within the HeLa cells, such as the lysosomes or the mitochondria. This study provided a successful case for the subsequent studies on biological imaging of NIR metal complexes bridged by N-heterocyclic ligands. 


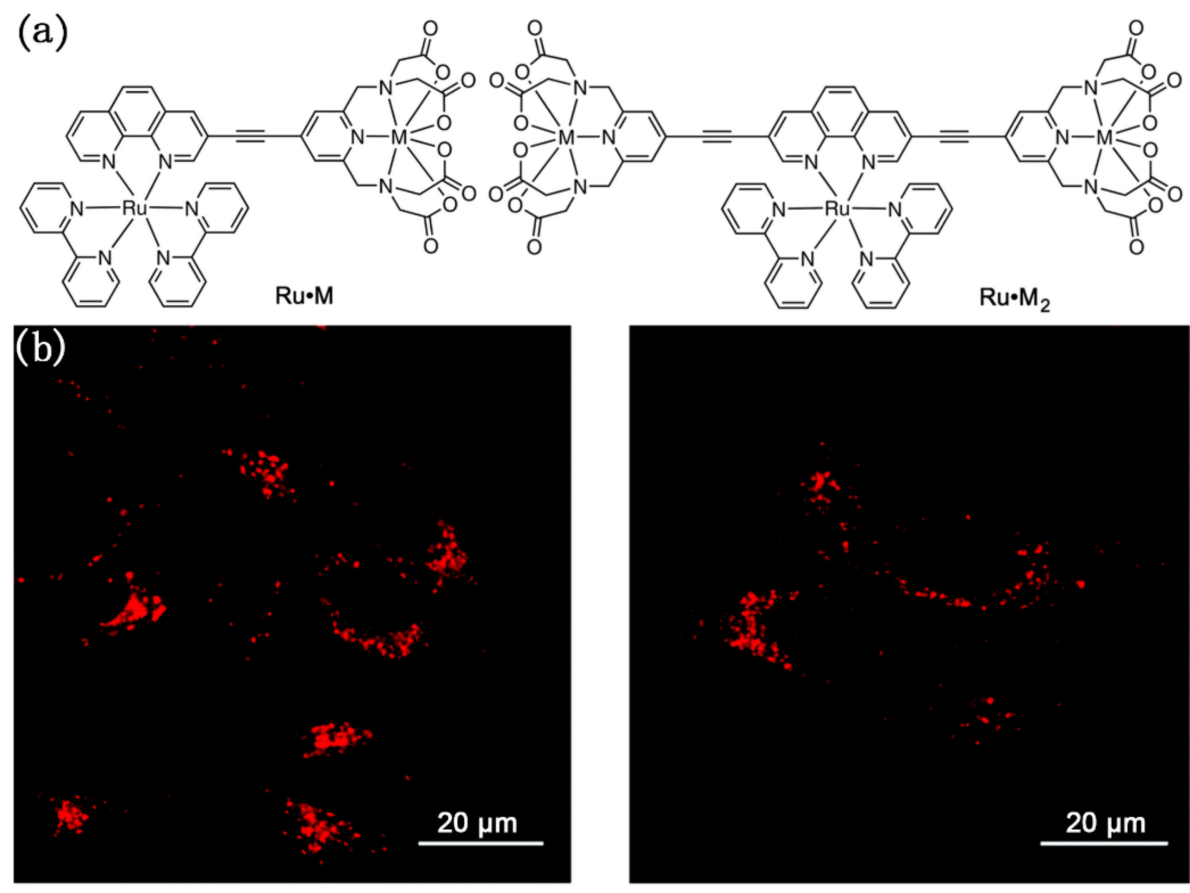

Figure 18. (a) The structure of $\mathbf{R u} \cdot \mathbf{M}$ and $\mathbf{R u} \cdot \mathbf{M}_{2}$; (b) Confocal microscopy images of HeLa cells incubated with $\mathbf{R u} \cdot \mathbf{G d}$ (left) or $\mathbf{R u} \cdot \mathbf{G d}_{\mathbf{2}}$ (right). Scale bars $=20 \mu \mathrm{m}$. Reprinted with permission from [92]. Copyright 2019, Royal Society of Chemistry.

\section{Summary and Perspectives}

This review introduces the recent development of NIR luminescent metal complexes with bridging ligands in the fields of electroluminescence, biosensing/bioimaging, etc. The luminescence behavior of metal complexes is directly related to the relative energy levels of metal ions and bridging ligands in excited states. Different energy level relationships lead to different excited states charge transfer directions between metal ions and organic ligands and induce different luminescence behaviors of metal complexes, which provide a theoretical basis for the preparation of luminescent metal complexes. Furthermore, small organic molecules, such as 4,4'-bipyridine, 2,2'-bipyrimidine, and ingeniously designed macromolecules such as polypyridine and polypyrrole molecules, used as bridging ligands have been described, which provides the strategies for the selection and design of bridging organic ligands. Thus, using these bridged ligands, the corresponding complexes with NIR luminescence properties have been synthesized and applied in the fields of electroluminescence and biological imaging.

Compared with visible light-emitting metal complexes with bridging ligands, which have been widely used in various fields, there is a lack of research on the practical application of NIR emitting bridged metal complexes. Most of the studies are still in the stage of researching the spectrum of NIR complexes with bridging ligands without material application. However, their great potential for practical application is still highly valued as new NIR luminescent materials due to the current research advances. Although there is a certain gap between the EQE of NIR complexes with bridging ligands and that of other materials currently used as the OLED emitting layer, rapid improvement has been achieved recently, which is incomparable by other materials.

Currently, the luminescence of most NIR emissive complexes comes from lanthanide ions, and organic ligands only serve to sensitize metal ions to emit light. This is also a key factor limiting the development of NIR complexes with bridging ligands, because (1) lanthanide metals are expensive, and (2) the performance of bridging ligands cannot be reflected in the luminescence behavior. Therefore, we believe that the next step in the development of NIR light-emitting complexes with bridging ligands is the design of bridging 
ligands to realize the wide applications: (1) Design organic ligands with excellent performance as bridges to coordinate with lanthanides metal ions, especially functional ligands with carboxyl groups. As mentioned above, the carboxyl group is an ideal bridging group. By itself, it can be used as a bridge group to coordinate with metal ions. Furthermore, it is easy to design bridging ligands with multiple carboxyl groups and metal ion coordination. (2) Design NIR luminescent bridging ligands to coordinate with cheap metal ions.

In short, although bridged near-infrared luminescent metal complexes have achieved corresponding progress, there is still much space for improvement in their performance and applications. This work may arouse widespread attention and provide help for the research of NIR luminescent complexes with bridging ligands.

Author Contributions: C.-J.Y. conceived the idea. J.-X.L. wrote the original manuscript. S.-L.M., X.-H.C. and C.-J.Y. co-wrote the paper. All authors have read and agreed to the published version of the manuscript.

Funding: We are grateful to the National Natural Science Foundation of China (Nos. 22075027, 52003030), Starting Grant from Beijing Institute of Technology (3020012222019) and financial support from the Beijing Institute of Technology Chongqing Innovation Center.

Conflicts of Interest: The authors declare no conflict of interest.

\section{References}

1. Wentrup, C. Zeise, Liebig, Jensen, Huckel, Dewar, and the Olefin pi-Complex Bonds. Angew. Chem. Int. Ed. 2020, 59, 8332-8342. [CrossRef] [PubMed]

2. Thomas, G.T.; Donnecke, S.; Paci, I.; McIndoe, J.S. Trichloro(Dinitrogen)Platinate(II). Chemistry 2020, 26, 12359-12362. [CrossRef] [PubMed]

3. Zhang, R.; Yuan, J. Responsive Metal Complex Probes for Time-Gated Luminescence Biosensing and Imaging. Acc. Chem. Res. 2020, 53, 1316-1329. [CrossRef] [PubMed]

4. Sun, Q.; Yang, K.; Ma, W.; Zhang, L.; Yuan, G. A highly stable 8-hydroxyquinolinate-based metal-organic framework as a selective fluorescence sensor for $\mathrm{Fe}^{3+}, \mathrm{Cr}_{2} \mathrm{O}_{7}{ }^{2-}$ and nitroaromatic explosives. Inorg. Chem. Front. 2020, 7, 4387-4395. [CrossRef]

5. Lo, K.K. Molecular Design of Bioorthogonal Probes and Imaging Reagents Derived from Photofunctional Transition Metal Complexes. Acc. Chem. Res. 2020, 53, 32-44. [CrossRef]

6. Şen, Z.; Gümüş, G.; Gürol, I.; Musluoğlu, E.; Öztürk, Z.Z.; Harbeck, M. Metal complexes of vic-dioximes for chemical gas sensing. Sens. Actuators B Chem. 2011, 160, 1203-1209. [CrossRef]

7. Zhu, X.; Wong, W.-K.; Wong, W.-Y.; Yang, X. Design and Synthesis of Near-Infrared Emissive Lanthanide Complexes Based on Macrocyclic Ligands. Eur. J. Inorg. Chem. 2011, 2011, 4651-4674. [CrossRef]

8. Sran, B.S.; Sharma, S.; Pointillart, F.; Cador, O.; Hundal, G. Field-Induced Single Molecular Magnetism and Photoluminescence in Rare Cocrystals of Isomorphic Lanthanide(III) Coordination Compounds with Fully Substituted Pyridine-4-carboxamide Ligand. Inorg. Chem. 2020, 59, 9227-9238. [CrossRef]

9. Huskic, I.; Novendra, N.; Lim, D.W.; Topic, F.; Titi, H.M.; Pekov, I.V.; Krivovichev, S.V.; Navrotsky, A.; Kitagawa, H.; Friscic, T. Functionality in metal-organic framework minerals: Proton conductivity, stability and potential for polymorphism. Chem. Sci. 2019, 10, 4923-4929. [CrossRef]

10. Li, T.T.; Zheng, Y.Q. Electrocatalytic water oxidation using a chair-like tetranuclear copper(ii) complex in a neutral aqueous solution. Dalton Trans. 2016, 45, 12685-12690. [CrossRef]

11. Luo, H.-K.; Wang, C.; Rusli, W.; Li, C.-Z.; Widjaja, E.; Wong, P.-K.; Stubbs, L.P.; Van Meurs, M. Highly active self-assembled group-IV-metal multinuclear catalysts for ethylene polymerization. J. Organomet. Chem. 2015, 798, 354-366. [CrossRef]

12. Liu, F.; Yang, F.; Chen, H.; Chen, Q.; Yan, P.; Li, G. Salen Type Homo-multinuclear $\mathrm{Yb}_{3}$ and Yb $\mathrm{Yb}_{4}$ Complexes and Their NIR Luminescence. J. Inorg. Organomet. Polym. Mater. 2014, 24, 259-266. [CrossRef]

13. Kilic, A.; Palali, A.A.; Durgun, M.; Tasci, Z.; Ulusoy, M.; Dagdevren, M.; Yilmaz, I. Synthesis, characterization, electrochemical properties and conversions of carbon dioxide to cyclic carbonates mononuclear and multinuclear oxime complexes using as catalyst. Inorg. Chim. Acta 2013, 394, 635-644. [CrossRef]

14. Nguyen, T.N.; Eliseeva, S.V.; Gladysiak, A.; Petoud, S.; Stylianou, K.C. Design of lanthanide-based metal-organic frameworks with enhanced near-infrared emission. J. Mater. Chem. A 2020, 8, 10188-10192. [CrossRef]

15. Shuvaev, S.; Parker, D. A near-IR luminescent ratiometric ytterbium pH probe. Dalton Trans. 2019, 48, 4471-4473. [CrossRef] [PubMed]

16. Nguyen, T.N.; Ebrahim, F.M.; Stylianou, K.C. Photoluminescent, upconversion luminescent and nonlinear optical metal-organic frameworks: From fundamental photophysics to potential applications. Coord. Chem. Rev. 2018, 377, 259-306. [CrossRef]

17. Bai, G.; Yang, Z.; Lin, H.; Jie, W.; Hao, J. Lanthanide Yb/Er co-doped semiconductor layered WSe 2 nanosheets with near-infrared luminescence at telecommunication wavelengths. Nanoscale 2018, 10, 9261-9267. [CrossRef] 
18. Martinic, I.; Eliseeva, S.V.; Nguyen, T.N.; Pecoraro, V.L.; Petoud, S. Near-Infrared Optical Imaging of Necrotic Cells by Photostable Lanthanide-Based Metallacrowns. J. Am. Chem. Soc. 2017, 139, 8388-8391. [CrossRef]

19. Creutz, S.E.; Fainblat, R.; Kim, Y.; De Siena, M.C.; Gamelin, D.R. A Selective Cation Exchange Strategy for the Synthesis of Colloidal $\mathrm{Yb}^{3+}$-Doped Chalcogenide Nanocrystals with Strong Broadband Visible Absorption and Long-Lived Near-Infrared Emission. J. Am. Chem. Soc. 2017, 139, 11814-11824. [CrossRef]

20. Müller, B.J.; Borisov, S.M.; Klimant, I. Red- to NIR-Emitting, BODIPY-Based, K+ ${ }^{+}$-Selective Fluoroionophores and Sensing Materials. Adv. Funct. Mater. 2016, 26, 7697-7707. [CrossRef]

21. Zhang, Z.; Zhou, Y.; Li, H.; Gao, T.; Yan, P. Visible light sensitized near-infrared luminescence of ytterbium via ILCT states in quadruple-stranded helicates. Dalton Trans. 2019, 48, 4026-4034. [CrossRef] [PubMed]

22. Zhu, Y.X.; Wei, Z.W.; Pan, M.; Wang, H.P.; Zhang, J.Y.; Su, C.Y. A new TPE-based tetrapodal ligand and its Ln(iii) complexes: Multi-stimuli responsive AIE (aggregation-induced emission)/ILCT(intraligand charge transfer)-bifunctional photoluminescence and NIR emission sensitization. Dalton Trans. 2016, 45, 943-950. [CrossRef] [PubMed]

23. Mazumdar, P.; Maity, S.; Das, D.; Samanta, S.; Shyamal, M.; Misra, A. Proton induced green emission from AIEE active 2,2'biquinoline hydrosol and its selective fluorescence turn-on sensing property towards $\mathrm{Zn}^{2+}$ ion in water. Sens. Actuators B Chem. 2017, 238, 1266-1276. [CrossRef]

24. Li, H.-Q.; Ding, Z.-Y.; Pan, Y.; Liu, C.-H.; Zhu, Y.-Y. Fluorescence tuning of Zn(II)-based metallo-supramolecular coordination polymers and their application for picric acid detection. Inorg. Chem. Front. 2016, 3, 1363-1375. [CrossRef]

25. VlcekJr, A. Mechanistic roles of metal-to-ligand charge-transfer excited states in organometallic photochemistry. Coord. Chem. Rev. 1998, 177, 219-256. [CrossRef]

26. Vincenzo, B.; Alberto, J.; Margherita, V.; Sebastiano, C.; Scolastica, S. Luminescent and Redox-Active Polynuclear Transition Metal Complexes. Chem. Rev. 1996, 96, 759-834.

27. Vogler, A.; Kunkely, H. Photoreactivity of metal-to-ligand charge transfer excited states. Coord. Chem. Rev. 1998, 177, 81-96. [CrossRef]

28. Xu, Y.; Du, C.; Zhou, C.; Yang, S. A new Ni-diaminoglyoxime-g- $\mathrm{C}_{3} \mathrm{~N}_{4}$ complex towards efficient photocatalytic ethanol splitting via a ligand-to-metal charge transfer (LMCT) mechanism. Chem. Commun. 2020, 56, 7171-7174. [CrossRef]

29. Ning, Y.; Zhu, M.; Zhang, J.-L. Near-infrared (NIR) lanthanide molecular probes for bioimaging and biosensing. Coord. Chem. Rev. 2019, 399. [CrossRef]

30. To, W.-P.; Wan, Q.; Tong, G.S.M.; Che, C.-M. Recent Advances in Metal Triplet Emitters with d6, d8, and d10 Electronic Configurations. Trends Chem. 2020, 2, 796-812. [CrossRef]

31. Zhang, Z.; Feng, W.; Su, P.; Liu, H.; Zhang, Y.; Wang, Z.; Miao, T.; Lu, X.; Fan, D.; Wong, W.K.; et al. Near-infrared (NIR) luminescent hetero-tetranuclear $\mathrm{Zn}_{2} \mathrm{Ln}_{2}(\mathrm{Ln}=\mathrm{Nd}$, $\mathrm{Yb}$ or $\mathrm{Er}$ ) complexes self-assembled from the benzimidazole-based $\mathrm{HL}$ and two rigid 4,4'-bipyridine ligands with different spacers. Spectrochim. Acta A Mol. Biomol. Spectrosc. 2013, 116, 102-110. [CrossRef] [PubMed]

32. Lü, X.; Bi, W.; Chai, W.; Song, J.; Meng, J.; Wong, W.-Y.; Wong, W.-K.; Jones, R.A. Tetranuclear NIR luminescent Schiff-base Zn-Nd complexes. New J. Chem. 2008, 32, 127-131. [CrossRef]

33. Singaravadivel, S.; Babu, E.; Velayudham, M.; Lu, K.-L.; Rajagopal, S. Sensitized near-infrared luminescence of lanthanide complexes by energy transfer from rhenium(I) complexes bridged by bis(benzimidazole) and phenanthrolino-5,6:5', $6^{\prime}$-pyrazine ligands. Inorg. Chim. Acta 2013, 400, 215-221. [CrossRef]

34. Shavaleev, N.M.; Accorsi, G.; Virgili, D.; Bell, D.R.; Lazarides, T.; Calogero, G.; Armaroli, N.; Ward, M.D. Syntheses and crystal structures of dinuclear complexes containing d-block and f-block luminophores. Sensitization of NIR luminescence from $\mathrm{Yb}$ (III), $\mathrm{Nd}(\mathrm{III})$, and $\mathrm{Er}(\mathrm{III})$ centers by energy transfer from $\operatorname{Re}(\mathrm{I})$ and $\mathrm{Pt}(\mathrm{II})$-bipyrimidine metal centers. Inorg. Chem. 2005, 44, 61-72. [CrossRef] [PubMed]

35. Li, H.-Y.; Wu, J.; Huang, W.; Zhou, Y.-H.; Li, H.-R.; Zheng, Y.-X.; Zuo, J.-L. Synthesis and photoluminescent properties of five homodinuclear lanthanide $\left(\mathrm{Ln}^{3+}=\mathrm{Eu}^{3+}, \mathrm{Sm}^{3+}, \mathrm{Er}^{3+}, \mathrm{Yb}^{3+}, \mathrm{Pr}^{3+}\right)$ complexes. J. Photochem. Photobiol. A Chem. 2009, 208, 110-116. [CrossRef]

36. Li, X.-L.; Liu, Y.-F.; Zhang, X.-L.; Cheng, C.; Zheng, X.; Zhu, C.; Zhou, L. Synthesis, crystal structures, photoluminescent, magnetic and chiroptical properties of two homochiral Er III complexes with different nuclearity. J. Mol. Struct. 2017, 1137, 27-32. [CrossRef]

37. Liu, B.; Monro, S.; Lystrom, L.; Cameron, C.G.; Colon, K.; Yin, H.; Kilina, S.; McFarland, S.A.; Sun, W. Photophysical and Photobiological Properties of Dinuclear Iridium(III) Bis-tridentate Complexes. Inorg. Chem. 2018, 57, 9859-9872. [CrossRef]

38. Gabr, M.T.; Pigge, F.C. Expanding the Toolbox for Label-Free Enzyme Assays: A Dinuclear Platinum(II) Complex/DNA Ensemble with Switchable Near-IR Emission. Molecules 2019, 24, 4390. [CrossRef]

39. Bulach, V.; Sguerra, F.; Hosseini, M.W. Porphyrin lanthanide complexes for NIR emission. Coord. Chem. Rev. 2012, 256, 1468-1478. [CrossRef]

40. Beeby, A.; Dickins, R.S.; FitzGerald, S.; Govenlock, L.J.; Parker, D.; Williams, J.A.G.; Maupin, C.L.; Riehl, J.P.; Siligardi, G. Porphyrin sensitization of circularly polarised near-IR lanthanide luminescence: Enhanced emission with nucleic acid binding. Chem. Commun. 2000, 1183-1184. [CrossRef]

41. Rusakova, N.; Semenishyn, N.; Korovin, Y. Heteronuclear lanthanide-containing complexes on the base of modified porphyrins and their luminescent properties. J. Porphyr. Phthalocyanines 2012, 14, 166-169. [CrossRef] 
42. Xiong, R.; Mara, D.; Liu, J.; Van Deun, R.; Borbas, K.E. Excitation- and Emission-Wavelength-Based Multiplex Spectroscopy Using Red-Absorbing Near-Infrared-Emitting Lanthanide Complexes. J. Am. Chem. Soc. 2018, 140, 10975-10979. [CrossRef] [PubMed]

43. Wang, Y.; Ogasahara, K.; Tomihama, D.; Mysliborski, R.; Ishida, M.; Hong, Y.; Notsuka, Y.; Yamaoka, Y.; Murayama, T.; Muranaka, A.; et al. Near-Infrared-III-Absorbing and -Emitting Dyes: Energy-Gap Engineering of Expanded Porphyrinoids via Metallation. Angew. Chem. Int. Ed. 2020, 59, 2-8.

44. Wu, L.; Li, F.; Rao, Y.; Wen, B.; Xu, L.; Zhou, M.; Tanaka, T.; Osuka, A.; Song, J. Synthesis, Structures, and Near-IR Absorption of Heterole-Fused Earring Porphyrins. Angew. Chem. Int. Ed. 2019, 58, 8124-8128. [CrossRef] [PubMed]

45. Xiong, R.; Andres, J.; Scheffler, K.; Borbas, K.E. Synthesis and characterisation of lanthanide-hydroporphyrin dyads. Dalton Trans. 2015, 44, 2541-2553. [CrossRef] [PubMed]

46. Mori, H.; Tanaka, T.; Lee, S.; Lim, J.M.; Kim, D.; Osuka, A. meso-meso linked porphyrin-[26]hexaphyrin-porphyrin hybrid arrays and their triply linked tapes exhibiting strong absorption bands in the NIR region. J. Am. Chem. Soc. 2015, 137, 2097-2106. [CrossRef]

47. Xu, Y.-Y.; Sun, O.; Qi, Y.; Xie, B.-Y.; Gao, T. Enhanced luminescence for detection of small molecules based on doped lanthanide compounds with a dinuclear double-stranded helicate structure. New J. Chem. 2019, 43, 16706-16713. [CrossRef]

48. Yang, X.; Schipper, D.; Jones, R.A.; Lytwak, L.A.; Holliday, B.J.; Huang, S. Anion-Dependent Self-Assembly of Near-Infrared Luminescent 24-and 32-Metal Cd-Ln Complexes with Drum-like Architectures. J. Am. Chem. Soc. 2013, 135, 8468-8471. [CrossRef]

49. Liu, J.; Yang, X.; Zhu, T.; Yuan, B.; Chen, H.; Shi, D.; Schipper, D.; Jones, R.A. Construction of a crystalline 14-metal Zn-Nd rectangular nanocluster with a dual-emissive response towards metal ions. RSC Adv. 2019, 9, 40017-40022. [CrossRef]

50. Liu, J.; Zhu, T.; Yang, X.; Chen, H.; Shi, D.; Zhu, C.; Schipper, D.; Jones, R.A. Construction of a 1-D Sm(iii) coordination polymer with a long-chain Schiff base ligand: Dual-emissive response to metal ions. Inorg. Chem. Front. 2020, 7, 464-469. [CrossRef]

51. Sarwar, A.; Saharin, S.M.; Bahron, H.; Alias, Y. Synthesis, structures, luminescence and thermal stability of Visible/NIR emitting binuclear azomethine-Zn(II) complexes. J. Lumin. 2020, 223, 117227. [CrossRef]

52. Dong, W.-K.; Ma, J.-C.; Zhu, L.-C.; Sun, Y.-X.; Akogun, S.F.; Zhang, Y. A Series of Heteromultinuclear Zinc(II)-Lanthanide(III) Complexes Based on 3-MeOsalamo: Syntheses, Structural Characterizations, and Luminescent Properties. Cryst. Growth Des. 2016, 16, 6903-6914. [CrossRef]

53. Bi, W.-Y.; Lü, X.-Q.; Chai, W.-L.; Song, J.-R.; Wong, W.-K.; Yang, X.-P.; Jones, R.A. Effect of Heavy-Atom (Br) at the Phenyl Rings of Schiff-Base Ligands on the NIR Luminescence of their Bimetallic Zn-Nd Complexes. Z. Anorg. Allg. Chem. 2008, 634, 1795-1800. [CrossRef]

54. Yang, X.P.; Jones, R.A.; Wong, W.K.; Lynch, V.; Oye, M.M.; Holmes, A.L. Design and synthesis of a near infra-red luminescent hexanuclear Zn-Nd prism. Chem. Commun. 2006, 1836-1838. [CrossRef] [PubMed]

55. Wong, W.-K.; Liang, H.; Wong, W.-Y.; Cai, Z.; Li, K.-F.; Cheah, K.-W. Synthesis and near-infrared luminescence of 3d-4f bi-metallic Schiff base complexes. New J. Chem. 2002, 26, 275-278. [CrossRef]

56. Tereniak, S.J.; Carlson, R.K.; Clouston, L.J.; Young, V.G., Jr.; Bill, E.; Maurice, R.; Chen, Y.-S.; Kim, H.J.; Gagliardi, L.; Lu, C.C. Role of the Metal in the Bonding and Properties of Bimetallic Complexes Involving Manganese, Iron, and Cobalt. J. Am. Chem. Soc. 2014, 136, 1842-1855. [CrossRef] [PubMed]

57. Palacios, M.A.; Titos-Padilla, S.; Ruiz, J.; Manuel Herrera, J.; Pope, S.J.A.; Brechin, E.K.; Colacio, E. Bifunctional Zn(II)Ln(III) Dinuclear Complexes Combining Field Induced SMM Behavior and Luminescence: Enhanced NIR Lanthanide Emission by 9-Anthracene Carboxylate Bridging Ligands. Inorg. Chem. 2014, 53, 1465-1474. [CrossRef] [PubMed]

58. Acar, Y.; Coban, M.B.; Gungor, E.; Kara, H. Two New NIR Luminescencent Er(III) Coordination Polymers with Potential Application Optical Amplification Devices. J. Clust. Sci. 2020, 31, 117-124. [CrossRef]

59. Hasegawa, Y.; Matsui, T.; Kitagawa, Y.; Nakanishi, T.; Seki, T.; Ito, H.; Nakasaka, Y.; Masuda, T.; Fushimi, K. Near-IR Luminescent Yb-III Coordination Polymers Composed of Pyrene Derivatives for Thermostable Oxygen Sensors. Chem. Eur. J. 2019, 25, 12308-12315. [CrossRef]

60. Feng, X.; Shang, Y.; Zhang, H.; Li, R.; Wang, W.; Zhang, D.; Wang, L.; Li, Z. Enhanced luminescence and tunable magnetic properties of lanthanide coordination polymers based on fluorine substitution and phenanthroline ligand. RSC Adv. 2019, 9, 16328-16338. [CrossRef]

61. Wang, X.; Yan, P.; Li, Y.; An, G.; Yao, X.; Li, G. Highly Efficient White-Light Emission and UV-Visible/NIR Luminescence Sensing of Lanthanide Metal-Organic Frameworks. Cryst. Growth Des. 2017, 17, 2178-2185. [CrossRef]

62. Coban, M.B.; Erkarslan, U.; Oylumluoglu, G.; Aygun, M.; Kara, H. Hydrothermal synthesis, crystal structure and Photoluminescent properties; 3D Holmium(III) coordination polymer. Inorg. Chim. Acta 2016, 447, 87-91. [CrossRef]

63. Lü, X.; Bi, W.; Chai, W.; Song, J.; Meng, J.; Wong, W.-Y.; Wong, W.-K.; Yang, X.; Jones, R.A. Multinuclear NIR luminescent 1,4-BDC bridged Schiff-base complexes of Nd(III). Polyhedron 2009, 28, 27-32. [CrossRef]

64. Deshmukh, M.A.; Patil, H.K.; Bodkhe, G.A.; Yasuzawa, M.; Koinkar, P.; Ramanaviciene, A.; Shirsat, M.D.; Ramanavicius, A. EDTA-modified PANI/SWNTs nanocomposite for differential pulse voltammetry based determination of Cu(II) ions. Sens. Actuators B Chem. 2018, 260, 331-338. [CrossRef]

65. Oviedo, C.; Rodríguez, J. EDTA: The chelating agent under environmental scrutiny. Quim. Nova 2003, 26, 901-905. [CrossRef]

66. Sillanpää, M.; Rämö, J. Adsorption of metal-ethylenediaminetetraacetic acid chelates onto lake sediment. Chemosphere 2001, 45, 881-885. [CrossRef] 
67. Nirel, P.M.; Pardo, P.-E.; Landry, J.-C.; Revaclier, R. Method for EDTA speciation determination: Application to sewage treatment plant effluents. Water Res. 1998, 32, 3615-3620. [CrossRef]

68. Phillips, K.A.; Stonelake, T.M.; Horton, P.N.; Coles, S.J.; Hallett, A.J.; O’Kell, S.P.; Beames, J.M.; Pope, S.J.A. Dual visible/NIR emission from organometallic iridium(III) complexes. J. Organomet. Chem. 2019, 893, 11-20. [CrossRef]

69. Jankowski, R.; Zakrzewski, J.J.; Surma, O.; Ohkoshi, S.-i.; Chorazy, S.; Sieklucka, B. Near-infrared emissive Er(III) and Yb(III) molecular nanomagnets in metal-organic chains functionalized by octacyanidometallates(IV). Inorg. Chem. Front. 2019, 6, 2423-2434. [CrossRef]

70. Balashova, T.V.; Burin, M.E.; Ilichev, V.A.; Starikova, A.A.; Marugin, A.V.; Rumyantcev, R.V.; Fukin, G.K.; Yablonskiy, A.N.; Andreev, B.A.; Bochkarev, M.N. Features of the Molecular Structure and Luminescence of Rare-Earth Metal Complexes with Perfluorinated (Benzothiazolyl)phenolate Ligands. Molecules 2019, 24, 2376. [CrossRef]

71. Artizzu, F.; Atzori, M.; Liu, J.; Mara, D.; Van Hecke, K.; Van Deun, R. Solution-processable Yb/Er 2D-layered metallorganic frameworks with high NIR-emission quantum yields. J. Mater. Chem. C 2019, 7, 11207-11214. [CrossRef]

72. Liao, W.-M.; Li, C.-J.; Wu, X.; Zhang, J.-H.; Wang, Z.; Wang, H.-P.; Fan, Y.-N.; Pan, M.; Su, C.-Y. Homometallic Ln(III)-complexes from an ILCT ligand with sensitized vis-NIR emission, excitation-dependent PL color tuning and white-light emission. J. Mater. Chem. C 2018, 6, 3254-3259. [CrossRef]

73. Xiao, Y.-H.; Deng, Z.-P.; Zhu, Z.-B.; Huo, L.-H.; Gao, S. Rare earth metal-organic complexes constructed from hydroxyl and carboxyl modified arenesulfonate: Syntheses, structure evolutions, and ultraviolet, visible and near-infrared luminescence. Dalton Trans. 2017, 46, 16493-16504. [CrossRef] [PubMed]

74. de Jesus, R.A.; da Luz, L.L.; Santos, D.O.; Santana Costa, J.A.; Navickiene, S.; Gatto, C.C.; Alves Junior, S.; de Mesquita, M.E. Dual emission tunable in the near-infrared (NIR) and visible (VIS) spectral range by mix-LnMOF. Dalton Trans. 2015, 44, 17318-17325. [CrossRef]

75. Wang, S.F.; Yuan, Y.; Wei, Y.-C.; Chan, W.-H.; Fu, L.-W.; Su, B.-K.; Chen, I.Y.; Chou, K.-J.; Chen, P.-T.; Hsu, H.-F.; et al. Highly Efficient Near-Infrared Electroluminescence up to $800 \mathrm{~nm}$ Using Platinum(II) Phosphors. Adv. Funct. Mater. 2020, 30, 2002173. [CrossRef]

76. Hao, Z.; Li, M.; Liu, Y.; Wang, Y.; Xie, G.; Liu, Y. Near-infrared emission of dinuclear iridium complexes with hole/electron transporting bridging and their monomer in solution-processed organic light-emitting diodes. Dyes Pigments 2018, 149, 315-322. [CrossRef]

77. Wang, S.F.; Fu, L.W.; Wei, Y.C.; Liu, S.H.; Lin, J.A.; Lee, G.H.; Chou, P.T.; Huang, J.Z.; Wu, C.I.; Yuan, Y.; et al. Near-Infrared Emission Induced by Shortened Pt-Pt Contact: Diplatinum(II) Complexes with Pyridyl Pyrimidinato Cyclometalates. Inorg. Chem. 2019, 58, 13892-13901. [CrossRef]

78. Zampetti, A.; Minotto, A.; Cacialli, F. Near-Infrared (NIR) Organic Light-Emitting Diodes (OLEDs): Challenges and Opportunities. Adv. Funct. Mater. 2019, 29, 1807623. [CrossRef]

79. Ding, F.; Fan, Y.; Sun, Y.; Zhang, F. Beyond 1000 nm Emission Wavelength: Recent Advances in Organic and Inorganic Emitters for Deep-Tissue Molecular Imaging. Adv. Healthc. Mater. 2019, 8, 1900260. [CrossRef]

80. He, Y.; Fu, G.; Li, W.; Wang, B.; Miao, T.; Tan, M.; Feng, W.; Lü, X. Efficient near-infrared (NIR) polymer light-emitting diode (PLED) based on the binuclear $\left[\left(\mathrm{C}^{\wedge} \mathrm{N}\right)_{2} \operatorname{Ir}-\left(\right.\right.$ bis- $\left.\left.\mathrm{N}^{\wedge} \mathrm{O}\right)-\operatorname{Ir}\left(\mathrm{C}^{\wedge} \mathrm{N}\right)_{2}\right]$ complex with aggregation-induced phosphorescent enhancement (AIPE) character. J. Lumin. 2020, 218, 116847. [CrossRef]

81. Su, N.; Meng, F.; Chen, J.; Wang, Y.; Tan, H.; Su, S.; Zhu, W. Near-infrared emitting pyrazole-bridged binuclear platinum complexes: Synthesis, photophysical and electroluminescent properties in PLEDs. Dyes Pigments 2016, 128, 68-74. [CrossRef]

82. Wu, X.; Liu, Y.; Wang, Y.; Wang, L.; Tan, H.; Zhu, M.; Zhu, W.; Cao, Y. Highly efficient near-infrared emission from binuclear cyclo-metalated platinum complexes bridged with 5-(4-octyloxyphenyl)-1,3,4-oxadiazole-2-thiol in PLEDs. Org. Electron. 2012, 13, 932-937. [CrossRef]

83. Wu, X.; Chen, D.-G.; Liu, D.; Liu, S.-H.; Shen, S.-W.; Wu, C.-I.; Xie, G.; Zhou, J.; Huang, Z.-X.; Huang, C.-Y.; et al. Highly Emissive Dinuclear Platinum(III) Complexes. J. Am. Chem. Soc. 2020, 142, 7469-7479. [CrossRef] [PubMed]

84. Yan, C.; Zhang, Y.; Guo, Z. Recent progress on molecularly near-infrared fluorescent probes for chemotherapy and phototherapy. Coord. Chem. Rev. 2021, 427, 213556. [CrossRef]

85. Chen, M.; Feng, S.; Yang, Y.; Li, Y.; Zhang, J.; Chen, S.; Chen, J. Tracking the in vivo spatio-temporal patterns of neovascularization via NIR-II fluorescence imaging. Nano Res. 2020, 13, 3123-3129. [CrossRef]

86. Wan, H.; Yue, J.; Zhu, S.; Uno, T.; Zhang, X.; Yang, Q.; Yu, K.; Hong, G.; Wang, J.; Li, L.; et al. A bright organic NIR-II nanofluorophore for three-dimensional imaging into biological tissues. Nat. Commun. 2018, 9, 1171. [CrossRef]

87. Tsukasaki, Y.; Morimatsu, M.; Nishimura, G.; Sakata, T.; Yasuda, H.; Komatsuzaki, A.; Watanabe, T.M.; Jin, T. Synthesis and optical properties of emission-tunable PbS/CdS core-shell quantum dots for in vivo fluorescence imaging in the second near-infrared window. RSC Adv. 2014, 4, 41164-41171. [CrossRef]

88. Shafikov, M.Z.; Zaytsev, A.V.; Suleymanova, A.F.; Brandl, F.; Kowalczyk, A.; Gapinska, M.; Kowalski, K.; Kozhevnikov, V.N.; Czerwieniec, R. Near Infrared Phosphorescent Dinuclear Ir(III) Complex Exhibiting Unusually Slow Intersystem Crossing and Dual Emissive Behavior. J. Phys. Chem. Lett. 2020, 11, 5849-5855. [CrossRef]

89. Li, L.; Zhang, L.; Tong, X.; Li, Y.; Yang, Z.; Zhu, D.; Su, Z.; Xie, Z. Near-infrared-emitting AIE multinuclear cationic Ir(III) complex-assembled nanoparticles for photodynamic therapy. Dalton Trans. 2020, 49, 15332-15338. [CrossRef] 
90. Daniels, R.E.; McKenzie, L.K.; Shewring, J.R.; Weinstein, J.A.; Kozhevnikov, V.N.; Bryant, H.E. Pyridazine-bridged cationic diiridium complexes as potential dual-mode bioimaging probes. RSC Adv. 2018, 8, 9670-9676. [CrossRef]

91. Yang, S.; Feng, W.; Feng, G. Development of a near-infrared fluorescent sensor with a large Stokes shift for sensing pyrophosphate in living cells and animals. Anal. Chim. Acta 2018, 1034, 119-127. [CrossRef] [PubMed]

92. Crowston, B.J.; Shipp, J.D.; Chekulaev, D.; McKenzie, L.K.; Jones, C.; Weinstein, J.A.; Meijer, A.J.H.; Bryant, H.E.; Natrajan, L.; Woodward, A.; et al. Heteronuclear d-d and d-f Ru(ii)/M complexes [M = Gd(iii), Yb(iii), Nd(iii), Zn(ii) or Mn(ii)] of ligands combining phenanthroline and aminocarboxylate binding sites: Combined relaxivity, cell imaging and photophysical studies. Dalton Trans. 2019, 48, 6132-6152. [CrossRef] [PubMed] 